\title{
Abandono afetivo: os limites do direito na coerção de manifestações emocionais humanas
}

\section{Abandonment affective: the limits of law in the coercion of emo- tional human expressions}

\begin{abstract}
Arthur M. Ferreira Neto $^{[\mathrm{a}]}$, Luciana Gemelli Eick ${ }^{[\mathrm{b}]}$
${ }^{\text {[a] }}$ Mestre e Doutor em Filosofia pela PUCRS e Mestre e Doutorando em Direito pela Universidade Federal do Rio Grande do Sul. Professor da Faculdade de Direito da PUCRS e Advogado. Porto Alegre, RS-Brasil, e-mail: aferreiraneto@yahoo.com.br

${ }^{[b]}$ Especialista em Direito dos Contratos e Responsabilidade Civil pela UNISINOS. Mestranda em Fundamentos Constitucionais do Direito Público e do Direito Privado pela PUCRS. Advogada. Porto Alegre, RS-Brasil, e-mail: Igeick@gmail.com
\end{abstract}

\section{Resumo}

O presente artigo investiga o abandono afetivo e suas implicações jurídicas, a partir da análise crítica do acórdão proferido pelo Superior Tribunal de Justiça no Recurso Especial no 1.159.242/SP. Nesse contexto, aborda os argumentos jurídicos retratados no julgado paradigma. A seguir, discute acerca do princípio da dignidade da pessoa humana e a precificação do afeto, bem como a eficácia social da decisão que pretendeu regular a manifestação do cuidado afetivo. Ao final, conclui pelo desacerto da decisão quando da análise da negligência paterna, por tratar a questão como a mera busca do negligenciado pela satisfação pecuniária, sem qualquer contrapartida sentimental, o que poderia culminar até mesmo para acen- 
tuar o abismo afetivo já existentes, inobstante a louvável tentativa da Corte Superior de disciplinar tema deveras complexo.

Palavras-chave: Abandono afetivo. Superior Tribunal de Justiça. Indenização. Precificação do afeto. Negligência.

\begin{abstract}
This essay investigates affective abandonment and its legal implications from the critical analysis of the judgment of the Superior Court in Special Appeal No. 1159242/SP. In this context, discusses the legal arguments portrayed in a comparative case. Then discusses about the principle of human dignity and the precification of affect and social effectiveness of the decision that was intended to regulate the expression of affective care. In the end, it concluded that the decision were a mistake when they analyzed the paternal negligence, by treating the issue as the mere pursuit of neglected by pecuniary satisfaction, without any sentimental consideration, which could lead even to accentuate the existing emotional abyss, in spite of the laudable attempt of the Superior Court to discipline theme indeed complex.
\end{abstract}

Keywords: Affective abandonment. Superior Court of Justice. Monetary compensation. Princing of affection. Negligence.

\title{
Introdução
}

0 presente artigo tem, como propósito central, averiguar se toda e qualquer ação tipicamente humana pode ser alvo de controle e regulação por parte do direito, inclusive aquelas interações humanas que pressupõem alguma manifestação sensitiva espontânea, com intencionalidade autônoma e sincera do agente, como é o caso do afeto, carinho e atenção. Dito de outro modo, busca-se nesse estudo analisar se tanto o legislador, quanto o operador jurídico poderiam, por meio da dimensão coercitiva do direito, pretender imputar obrigação jurídica que exigiria o cumprimento de determinadas atitudes afetivas por parte das figuras parentais em relação aos seus filhos, de modo a impor sanções (i.e., o pagamento de indenização pecuniária) em caso de não atendimento satisfatório desse suposto dever jurídico. A relevância e a atualidade dessa discussão surge em razão do Acórdão proferido pela 3a Turma do Superior Tribunal de Justiça, quando do julgamento do RESP 1.159.242, 
a qual, em 24/04/12, entendeu por maioria que o chamado "abandono afetivo" por parte dos genitores em relação aos seus filhos refletiria dano moral passível de ser regulado pelo Direito e de ser objeto de reparação pecuniária por meio de indenização.

Importante ressaltar que não se almeja aqui apresentar tãosomente comentários ao referido julgado com objetivo de analisar a retidão das questões técnico-jurídicas enfrentadas no caso, de modo a averiguar a sua compatibilidade ou não com a dogmática civilista ou com o próprio Código Civil. Não se visa, portanto, a enfrentar aqui as considerações pertinentes ao tema da responsabilidade civil em si considerada, de modo que não se busca, neste estudo, reconstruir e readequar os conceitos de culpa, dano, nexo causal etc... Isso porque, conforme se pretende demonstrar, as questões envolvendo o suposto dever de indenizar nos casos de "abandono afetivo" de nenhum modo podem ser enfrentadas apenas a partir da ótica civilista, na medida em que esse debate toca em pressupostos fundamentais da teoria do direito, exigindo, pois, seja esclarecida, previamente, a efetiva função coordenadora do direito e sejam, assim, definidos os verdadeiros limites regulatórios do direito. Desse modo, o presente estudo assume escopo expressivamente mais amplo, já que se pretende enfrentar a referida questão jurídica a partir da perspectiva da filosofia do direito e da teoria do direito, com o intuito de se averiguar se, dentre todas as ofensas a bens imateriais (tais como honra, consciência, imagem) que são passíveis de indenização, a falha em dedicar afeto, carinho, atenção também se encontra entre esses bens intangíveis que podem ser controlados e coordenados pela nossa prática jurídica.

Ressalte-se, desde já, que os autores de nenhum modo entendem como louvável ou digna de elogio a postura de um pai que não demonstra afeto ou que não dedica atenção emotiva ao seu filho. Não se pretende, pois, por meio deste artigo, elaborar argumentos que servirão de proteção especial a pais negligentes e omissos em relação a seus filhos. Os autores, certamente, compartilham da visão comum de que um indivíduo que não demonstra afeto, carinho e atenção para com a sua prole manifesta alguma espécie de corrupção de caráter e assume atitude moralmente reprovável, a qual, inclusive, pode se justificar em razão de inúmeros fatores sociológicos e psicológicos (e.g., algum distúrbio emocional ou até algum transtorno psíquico). 
Dito isso, mostra-se evidente que sempre existirão pais, concretamente considerados, que não estarão capacitados a direcionar verdadeiro afeto aos seus filhos, seja por inabilidade, seja por compromissos excessivos assumidos em outras áreas da vida ou seja ainda em razão de evidentes desvios de personalidade que o impedem de demonstrar o necessário cuidado emocional que um ser humano em formação necessita. Assim, não é novidade - nem deveria ser algo espantoso - conceber a ideia de que existem pais que não demonstram carinho, afeto e atenção a seus filhos, do mesmo modo que existem amigos, noivos(as)/cônjuges/companheiros que nos desiludem e que existem pessoas sem qualquer sentimento de compaixão pelo próximo. Do traço reprovável dessa atitude omissiva, porém, não se poderá extrair a imediata e precipitada conclusão de que caberá ao direito corrigir tais defeitos humanos, principalmente por meio da imposição de sanções monetárias ao pai com deficiências emocionais. É o que se pretende neste estudo demonstrar.

\section{O contexto fático e jurídico do caso enfrentado no RESP}

\subsubsection{2-SP}

O Superior Tribunal de Justiça, ao julgar o Recurso Especial $n$. 1.159.242 - SP, interposto contra Acórdão proferido pelo Tribunal de Justiça do Estado de São Paulo, enfrentou caso em que a litigante ajuizou Ação Indenizatória contra seu genitor, visando à reparação por danos materiais e compensação por danos morais, ao argumento de que teria sido vítima de abandono afetivo por parte de seu pai, o qual jamais teria lhe dedicado carinho, atenção e cuidado emocional durante o período de sua infância e juventude. Em primeira instância, a pretensão da filha foi julgada improcedente, pois, por meio da prova testemunhal colhida, restou provado que o distanciamento ocorrido entre pai e filha deveu-se ao constante comportamento agressivo apresentando pela genitora da Autora. Fator esse que veio a impedir que o pai se fizesse presente nos mais importantes momentos da vida da filha. 0 julgador de primeiro grau, ao prolatar a sentença, destacou os seguintes fatos relatados pelas testemunhas inquiridas: 
A prova produzida demonstra que não existiu e não existe convívio entre autora e réu, filha e pai e tal situação decorre do comportamento agressivo da genitora da autora em relação ao requerido.

Tal fato é relatado pelas testemunhas inquiridas na audiência de instrução, inclusive incidentes ocorridos no casamento do requerido, onde a genitora da autora se fez presente visando tumultuar a cerimônia. Esteve também na residência do requerido e em seu local de trabalho, promovendo escândalos, inclusive arremessando pedras contra a casa do mesmo.

Na data da audiência, nos corredores do Fórum, agrediu fisicamente o requerido e ameaçou as testemunhas que seriam inquiridas.

Tais fatos demonstram que a aproximação do requerido, à autora, sua filha, principalmente nas datas por ela mencionadas, como natal, formatura, aniversário, etc., era praticamente impossível, dado o comportamento agressivo da genitora da autora.

Inconformada, recorreu a Autora pleiteando a total reforma da sentença, tendo o Tribunal de Justiça, por sua vez, dado provimento ao recurso interposto, reconhecendo o dano afetivo causado pelo Recorrido, seu pai, oportunidade em que a indenização por danos morais restou arbitrada em $\mathrm{R} \$ 415.000,00^{1}$.

O Genitor, inconformado com sua condenação a pagar quantia pecuniária em favor de sua filha, em razão de suposto abandono emocional, interpôs Recurso Especial, alegando que não houve qualquer prática negligente de sua parte passível de gerar dever de indenizar e, ainda que tal fato tivesse ocorrido, esse evento não caracteriza conduta juridicamente ilícita. Ressaltou que a única sanção possível de ser aplicada seria a perda do poder familiar, tal como prevista no art. 1638 do Código Civil de $2002^{2}$. Alternativamente, pugnou pela redução do valor da condenação.

\footnotetext{
${ }^{1}$ Restou assim ementado o referido Acórdão: “Ação de indenização. Danos morais e materiais. Filha havida de relação amorosa anterior. Abandono moral e material. Paternidade reconhecida judicialmente. Pagamento de pensão arbitrada em dois salários mínimos até a maioridade. Alimentante abastado e próspero. Improcedência. Apelação. Recurso parcialmente provido." (TJSP, 7ạ Câmara "B" de Direito Privado, Desembargadora Daise Fajardo Jacot)

${ }^{2}$ Art. 1.638. Perderá por ato judicial o poder familiar o pai ou a mãe que: I - castigar imoderadamente o filho; II - deixar o filho em abandono; III - praticar atos contrários à moral e aos bons costumes; IV incidir, reiteradamente, nas faltas previstas no artigo antecedente.
} 
Apreciando tal Recurso Especial - que recebeu o número 1.159.242 -, a $3^{\text {a }}$ Turma do STJ, em voto de relatoria da Ministra Nancy Andrighi, acabou dando parcial provimento ao recurso interposto pelo genitor, entendendo, por maioria, que o abandono afetivo cometido pelo pai em relação a sua filha ensejaria dano moral passível de ser corrigido pelo direito e de ser objeto de reparação pecuniária por meio de indenização. Desse modo, a referida decisão da Corte Superior manteve, em parte, o Acórdão prolatado pelo Tribunal de Justiça de São Paulo, reduzindo, no entanto, a condenação para $\mathrm{R} \$ 200,000,00^{3}$.

No que se refere aos esclarecimentos fáticos do caso, mostrou-se, ainda, bastante esclarecedor o voto-vista do Ministro Sidnei Beneti, o qual destacou relevantes elementos casuísticos que pautaram a situação concreta analisada, especialmente no que se refere aos fatores que teriam permitido, in casu, a caracterização do abandono paterno. Destacou o Ministro os seis atos que a filha abandonada havia invocado como ilícitos que teriam sido cometidos pelo seu pai, os quais acarretariam o dano moral ensejador de indenização, quais sejam:

1 - 0 genitor teria adquirido propriedades, por simulação, em nome dos outros filhos;

$2^{\circ}$ - Não teria ele dado atenção às reclamações da filha em relação à simulação praticada;

3o - Jamais veio o pai a demonstrar carinho, afeto, amor, atenção, apoio moral, nunca tendo a filha sentado no colo do pai, não tendo recebido conselhos paternais, ajuda na escola, cultural e financeira etc..;

4 o - Teria sido o pai negligente no auxílio em despesas médicas, escolares, abrigo, vestiário e outras;

5 - Teria o genitor apenas efetuado o pagamento de pensão alimentícia de modo compulsório, por meio de imposição judicial; e

6 o - O reconhecimento do vínculo parental somente teria se dado por meio de processo judicial.

Com base em tais elementos fáticos, o Ministro Sidnei Beneti votou pelo provimento parcial do Recurso Especial interposto, apenas para reduzir o valor da condenação para $\mathrm{R} \$ 200.000,00$ (duzentos mil reais).

\footnotetext{
${ }^{3}$ Os Srs. Ministros Sidnei Beneti, Paulo de Tarso Sanseverino e Ricardo Villas Boas Cueva votaram com a Sra. Ministra Relatora, restando vencido o voto do Sr. Ministro Massami Uyeda.
} 
Em sentido contrário foi o voto do Ministro Massami Uyeda, o qual entendeu não existir direito a indenização no caso, na medida em que impassível de controle jurídico o dever de garantir aos filhos atenção e carinho paternos. 0 Ministro Uyeda assim afirmou:

o ideal da convivência das pessoas é que todos tivéssemos uma vida em família harmoniosa, com o pai e a mãe expedindo esse amor, esse carinho, mas manifestações de amor e carinho é meio complexo. Não posso exigir que os meus padrões psicológicos se coloquem na normalidade.

Do mesmo modo o Sr. Ministro Massami Uyeda assim questionou:

o que é a negligência no sentido do dever, do pátrio dever? Não sei. Nós mesmos, como pais, avós, temos inúmeras falhas. As crianças, os filhos, hoje, já são adultos e podem até reclamar, e até com muita razão. Então, abrir essa porta aqui, reconhecer isso como um direito não podemos, como todo o respeito. Existe uma lesão à estima. Todos nós...A nossa vida é feita de perdas e ganhos, talvez até mais de perdas do que de ganhos.

Por fim, o Ministro Paulo de Tarso Sanseverino acompanhou a postura majoritária formada no caso, também concedendo parcial provimento ao Recurso Especial interposto, admitindo a redução do valor da indenização.

Como se vê, portanto, a lide posta à apreciação da Corte Superior envolveu situação concreta de conflito de natureza emotivo surgido entre pai e filha, na qual o primeiro teria cometido o denominado "abandono afetivo" relativamente à segunda, na medida em que, mesmo que tivesse arcado - compulsoriamente - com as prestações alimentícias exigidas de um genitor, garantindo, pois, os recursos financeiros para o provimento dos meios necessários à subsistência e ao desenvolvimento básico da criança por ele gerada, teria ele se omitido "da prática de fração dos deveres inerentes à paternidade" 4 , mais especificamente, deveres de manifestação de atitudes de carinho, afeto, preocupação e participação ativa em atividades realizadas por sua filha. Assim, de acordo com o entendimento que prevaleceu junto à 3a Turma do STJ, no RESP 1159242, tais práticas omissivas do genitor seriam "elemento

\footnotetext{
${ }^{4}$ Expressão utilizada pela Ministra Nancy Andrighi no voto do Recurso Especial n. 1.159.242-SP, p. 5.
} 
suficiente para caracterizar dano moral compensável" (Superior Tribunal de Justiça, p. 5).

No que tange à questões de fundamentação jurídica do caso, a Ministra Nancy Andrighi, relatora do caso e responsável pelo voto que capitaneou a postura majoritária do órgão julgador, construiu o seu iter decisório a partir de uma série de argumentos inovadores (o que não significa dizer que sejam necessariamente corretos), principalmente por introduzir novos elementos que não são, em regra, invocados em decisões judiciais (e.g., considerações multidisciplinares como as lições do psicanalista Donald Winnicott), como também acabou se escorando em premissas que podem não ser compatíveis com a natureza do fenômeno jurídico, na medida em que ampliam a função regulatória do direito, ao ponto de pretender impor ou coordenar a prática de ações humanas que não são passíveis coerção nem controle estatal, obscurecendo, assim, os limites que devem existir entre moral e direito. Cabe, pois, nesta etapa introdutória deste estudo, identificar e detalhar os principais argumentos que compuseram a ratio decidendi do voto proferido pela Ministra Andrighi no caso mencionado.

Primeiramente, identificamos no referido Voto o argumento que se funda na própria sistematização interna de nosso direito positivo, o qual aqui escolhemos denominar de "dever de indenizar em razão da ausência de impedimento legal". Quanto a esse ponto, a Ministra Andrighi ressaltou que as relações intrafamiliares, mesmo que permeadas por elementos subjetivos, como sentimentos e emoções, não estariam fora do escopo da possibilidade compensatória, tipicamente, tratada pelo direito, razão pela qual seria possível identificar danos jurídicos causados por um genitor negligente que não tenha cumprido com as suas "obrigações parentais", o que permitiria a sua condenação a pagar indenização pecuniária àquele que tenha sofrido o correspondente abalo provocado pela não recepção de cuidado, atenção, carinho etc... Com efeito, partindo aprioristicamente da premissa de que existe dano moral nas relações familiares, entendeu a Ministra Andrighi que poderia ser superado o fato de não haver previsão legal expressa que preveja condenação para os casos do chamado abandono afetivo, alegando que "não existem restrições legais à aplicação das regras relativas à responsabilidade civil e o consequente dever de indenizar/compensar, no Direito de Família" (Superior Tribunal de Justiça, p. 5). 
Como se vê, o primeiro argumento que será analisado criticamente nos tópicos seguintes deste artigo, pressupõe que do fato de não haver impedimentos legais à responsabilização jurídica dos pais deve-se concluir que esses podem ser condenados a indenizar seus filhos em situações de conflito emocional-afetivo intraparental. Veremos, portanto, que o denominado argumento do "dever de indenizar em razão da ausência de impedimento legal" sofre das deficiências da circularidade e da derivação imprópria.

0 segundo argumento que veio a ser adotado pela Ministra Andrighi, o qual também merece ser submetido ao escrutínio de nossa crítica, pode ser aqui qualificado como sendo "a possibilidade de mensuração, controle e regulação estatal dos processos emocionais internos dos indivíduos", de modo que seria possível avaliar a qualidade da sua manifestação externa direcionada a terceiros. Se o primeiro argumento se escorra em possível lacuna legislativa no que se refere à imputação de dever de indenizar por falhas em manifestações afetivo-emocionais dos pais em relação ao seus filhos, o segundo argumento a ser aqui analisado irá especular a própria viabilidade e a legitimidade de, mesmo havendo dispositivos legais que anunciem, expressamente, deveres parentais de cuidado e afeto, se pretender criar - especialmente por via jurisprudencial - instrumentos de controle quantitativos e qualitativos acerca do tipo e do grau de manifestação afetiva que pais devem dedicar aos seus filhos.

Neste ponto, a Ministra deixa claro, desde o início do seu Voto, que a atitude omissiva que estará sendo analisada, de modo a verificar se poderia ela ter gerado dano moral juridicamente indenizável, envolve "alto grau de subjetividade", uma vez que pressupõe a análise concreta de relações familiares que tenham ou não manifestado "afetividade, amor, mágoa" (Superior Tribunal de Justiça, p. 6). Mesmo diante da dificuldade de se identificar, com alguma precisão jurídica, tais "elementos intangíveis", sustenta a Ministra que existiria um núcleo de objetividade nas relações entre pais e filhos que seria derivada do vínculo biológico ou mesmo auto-imposto (e.g. Adoção), de modo que exsurgiria disso obrigações emocionais mínimas que, quando descumpridas, gerariam dever de indenizar. Entende a ministra que, dentre os deveres de criação e educação da figura paternal está o de "transmissão de atenção e o acompanhamento do desenvolvimento sócio-pedagógico da criança" 
(Superior Tribunal de Justiça, p. 7). Com isso, reconhece que a questão de fundo toca em avaliação e mensuração de manifestações emotivas e afetivas de indivíduos. Portanto, conclui a Ministra Andrighi, no caso em pauta, estarem presentes os elementos necessários à caracterização do dano moral, pois configurados os três elementos básicos da responsabilidade civil subjetiva, quais sejam, o dano, a culpa e o nexo causal. Nesse ponto, caberá averiguar a pertinência de argumento filosófico-jurídico preliminar, ou seja, anterior a identificação da presença, nos casos do chamado abandono afetivo, do trinômio básico da responsabilidade civil, que questiona a própria capacidade regulatória do direito em relação a comportamentos humanos que se calcam em processos emocionais internos que podem não ser capazes de receberem controle estatal e de sofrerem coerção jurídica (sob pena de absoluta ineficácia da medida). Isso se deve, como se pretende argumentar, não tanto pelo alto grau de subjetividade das manifestações humanas de afeto, carinho e atenção, mas pelo seu traço, de um lado, tanto espontâneo e quanto, de outro, puramente autônomo de manifestação individual.

Essa questão toca, diretamente, em argumento auxiliar construído pela Ministra Andrighi em seu Voto, envolvendo suposta conotação voluntária dos vínculos emotivos que devem ser mantidos entre pais e filhos. Isso porque defende a Ministra que a formação do vínculo parental seria "fruto, sempre, de ato volitivo" (Superior Tribunal de Justiça, p. 7) do genitor (negrito no original), o que, em sua visão, justificaria a responsabilização jurídica da figura parental que tivesse, voluntariamente, escolhido não manifestar cuidados afetivo-emocionais em relação a seus filhos. Isso porque estando tais manifestações sensitivas dentro do escopo do livre arbítrio humano, seria perfeitamente viável ao direito controlar tais manifestações volitivas e penalizar os seus eventuais desvios. Como se pretende argumentar, o pressuposto da "natureza voluntária dos vínculos emocionais", além de um tanto contraintuitivo, representa tese, não só jurídica, mas filosófica, antropológica e psicológica de difícil comprovação5.

\footnotetext{
5 Esse argumento em particular pode ser analisado em escopo ainda mais amplo daquele que seria exigido pelo caso concreto em análise, ou seja, não necessita ficar adstrito apenas às relações familiares, pois se sustentará que, em realidade, nenhuma relação afetiva e emocional, mesmo que possa pressupor uma parcial influência de atos intencionais do indivíduo, jamais poderia ser caracterizada como ato puramente voluntário do sujeito que deveria manifestar essa ou aquela atitude emocional.
} 
Por fim, encontramos o argumento que acabou se tornando o mais célebre dentre aqueles ventilados pela Ministra Andrighi no caso aqui sendo estudado, por meio do qual a Ministra, objetivando não incorrer nas dificuldade de se quantificar manifestações emocionais e buscando garantir um verniz de objetividade à suposta ilicitude por ela identificada na ação omissiva do genitor, confecciona um novo conceito técnicojurídico apresentado como sendo o "cuidado paterno", o qual se diferenciaria do "amor paterno". Denominaremos esse argumento de "a fabricação do conceito de cuidado afetivo". Na percepção da Ministrarelatora, uma vez não cumprido de maneira adequada tais deveres jurídicos de "cuidado paterno", justificada estaria a indenização pecuniária em benefício do filho. Nesse sentido, assim estabelece a Ministra:

(...) constituindo-se o cuidado fator crucial à formação da personalidade do infante, deve ele ser alçado a um patamar de relevância que mostre o impacto que tem na higidez psicológica do futuro adulto. Nessa linha de pensamento, é possível se afirmar que tanto pela concepção, quanto pela adoção, os pais assumem obrigações jurídicas em relação à sua prole, que vão além daquelas chamadas necessarium vitae. ${ }^{6}$

Pelo que se extrai dessa afirmação, nenhuma novidade veio de fato a ser introduzida por essa constatação genérica, uma vez que, ao menos no Direito Contemporâneo, ninguém seriamente sustenta a ideia de que o pai, financeiramente estável, deve fornecer ao seu filho apenas os meios materiais necessários à sua subsistência física. Obviamente, toda e qualquer figura paterna deverá promover as condições materiais para que o seu filho possa receber as todas as oportunidades necessárias para o seu pleno desenvolvimento humano, o que pressupõe recursos financeiros, não apenas para alimentação e saúde, mas também para o custeio de "educação, lazer, [aprendizagem] de regras de conduta" (são expressões usadas pela Ministra em seu voto). Aliás, não seria exagero considerar como despesa necessária a ser arcada pelos pais os valores a serem gastos com acompanhamento psicológico do filho, caso seja esse

Não se pode negar, por outro lado, que esse falso pressuposto, coerentemente, representaria, de fato, pressuposto indispensável para a responsabilização jurídica nos casos do denominado "abandono afetivo".

${ }^{6}$ Expressão utilizada pela Ministra Nancy Andrighi no voto do Recurso Especial n. 1.159.242-SP, p. 8. 
tipo de tratamento indispensável para o pleno desenvolvimento da criança ou, inclusive, o seu reestabelecimento psíquico, na hipótese de algum trauma infantil que tenha sofrido (e.g. a separação dos pais). Ocorre que todos esses elementos indispensáveis à formação integral da criança, apontados pela Ministra Andrighi, que, obviamente vão muito além do mero custeio das condições materiais para a sua subsistência orgânica da criança, pressupõem, prioritariamente, a existência de recursos financeiros para o seu custeio, de modo que o genitor que, tendo condições econômicas, não fornece tais bens e oportunidades estará, de fato, cometendo ilícito omissivo, passível de gerar indenização. Essa constatação, no entanto, de nenhum modo permite concluir que o pai estará juridicamente obrigado a demonstrar determinadas atitudes emotivas em relação aos seus filhos. Isso porque dentro do cenário projetado pela Ministra, o dano que ainda estará sendo reparado nas situações descritas ainda será tipicamente material, uma vez que causado pela não disponibilização de bens de repercussão econômica direta que deveriam ser fornecidos e acessados pela criança. Assim, continuamos na esfera da indenização material quando apuramos quanto o pai deve arcar para financiar a educação formal, o lazer e, inclusive, o atendimento por profissionais especializados que venham a tratar eventuais traumas psicológicos que a criança tenha sofrido por atitudes intencionais ou não intencionais dos seus genitores. Caberá, pois, analisar no próximo tópico em que medida a fabricação do conceito de "cuidado afetivo" se sustenta.

\section{Análise crítica dos argumentos jurídicos adotados no RESP 1.159.242-SP}

\section{1. "O dever de indenizar em razão da ausência de impedimento legal"}

0 primeiro argumento adotado no voto condutor proferido no RESP 1.159.242 mostra manifestamente improcedente, na medida em que comete derivação imprópria da premissa que aparentemente adota. Isso ocorre porque, no direito, jamais se pode concluir, automaticamente, que, em não havendo proibição legal expressa, possa-se sempre estabelecer uma determinada imputação jurídica. Ora, existem infinitas 
relações humanas e sociais que, pela sua própria natureza interna (a ser posteriormente esclarecida), não poderão ser jamais captadas nem coordenadas pelo direito, havendo ou não dispositivo legal que se arrogue da pretensão de regular tal esfera de interação humana.

0 argumento, em verdade, especula em cima de simples constatação negativa acerca do conteúdo do nosso ordenamento jurídico, a qual se pauta na equivocada ideia de que, diante da ausência de disposição legal que exclua determinadas relações parentais do dever de indenizar, favorável deveria ser considerada a pretensão daquele que sofreu o chamado abandono afetivo. Percebe-se, de pronto, uma fraqueza argumentativa nesse tipo de constatação, pois ela apenas se fia na existência contingente de uma lacuna legislativa para alcançar a conclusão de que, diante da carência de disposição legal, regulada pelo direito estaria a situação em pauta. Mostra-se evidente, no entanto, que nenhuma fundamentação jurídica minimamente aceitável poderia ser justificada pela só demonstração circular que parte (i) da afirmação apriorística de que existem obrigações jurídicas intrafamiliares que impõe aos pais deveres jurídicos de afeto e atenção, na medida em que inexistiria qualquer impedimento legal, de modo que (ii) essas obrigações, quando não cumpridas, provocam danos psicológicos a integrantes desse núcleo familiar, de modo que (iii) tais danos, tendo sido definidos previamente como estando dentro do escopo de obrigações reguladas pelo direito, deveriam ser reparados.

Se assim fosse, qualquer aspecto de uma relação intraparental que viesse a ser frustrado ou em qualquer situação em que não atendidos à satisfação os desejos dos filhos poderia ser alegado que teria sido cometido algum dano gerador de um dever de indenizar, o que, por óbvio, provocaria situações absurdas. Por exemplo, trilhando o argumento do "dever de indenizar em razão da ausência de impedimento legal", o não pagamento de mesada pelos pais aos filhos (talvez por alguma dificuldade financeira momentânea) estaria sem dúvida alguma violando elementos de uma relação que poderiam ser reproduzida (artificialmente) em termos aparentemente jurídicos, tendo em vista o rompimento de expectativas legítimas dos filhos (agredindo, assim, uma possível noção de "segurança jurídica"), bem como o descumprimento de promessas feitas no passado (afrontando, assim, a ideia do pacta sunt servanda). No entanto, soa absurdo imaginar que, pelo só-fato de inexistir impedi- 
mento legal expresso que proíba esse tipo de pretensão indenizatória, viesse a ser admitida pelo Judiciário a procedência de ações reparatórias dessa natureza.

Em segundo lugar, outro aspecto do argumento do "dever de indenizar em razão da ausência de impedimento legal" deve ser aqui apreciado. Como se viu, esse argumento sustenta que a lacuna legislativa seria indicativo da possibilidade de o Judiciário construir bases normativas para identificar casos de abandono afetivo passíveis de qualificação como ilícitos a serem reparados pelo direito. Ocorre que, caso se ampliasse essa linha de argumentação, se poderia ainda pretender sustentar que, mesmo não sendo legítima a derivação que parte da ausência de impedimento legal, ainda assim seria possível localizar no ordenamento jurídico determinadas normas positivas que estariam prevendo expressamente o dever jurídico de os pais dedicaram afeto, carinho e atenção ao seus filhos, o que, por si só, tornariam jurídicas tais relações familiares que impõem obrigações afetivas, sob pena de as figuras paternas terem que arcar com indenizações.

Em regra, com o propósito de se sustentar a positivação dos deveres jurídicos que coíbem o abandono afetivo, são invocados para os artigos 227 da Constituição Federal ${ }^{7}$, os artigos 15 a 18 do Estatuto da Criança e do Adolescente ${ }^{8}$ e artigo 1634 do Código Civil ${ }^{9}$. No entanto, a

\footnotetext{
${ }^{7}$ Art. 227. É dever da família, da sociedade e do Estado assegurar à criança, ao adolescente e ao jovem, com absoluta prioridade, o direito à vida, à saúde, à alimentação, à educação, ao lazer, à profissionalização, à cultura, à dignidade, ao respeito, à liberdade e à convivência familiar e comunitária, além de colocá-los a salvo de toda forma de negligência, discriminação, exploração, violência, crueldade e opressão.

${ }^{8}$ Art. 16. O direito à liberdade compreende os seguintes aspectos: (...) V - participar da vida familiar e comunitária, sem discriminação;

Art. 17. O direito ao respeito consiste na inviolabilidade da integridade física, psíquica e moral da criança e do adolescente, abrangendo a preservação da imagem, da identidade, da autonomia, dos valores, ideias e crenças, dos espaços e objetos pessoais.

Art. 18. É dever de todos velar pela dignidade da criança e do adolescente, pondo-os a salvo de qualquer tratamento desumano, violento, aterrorizante, vexatório ou constrangedor.

Art. 18-A. A criança e o adolescente têm o direito de ser educados e cuidados sem o uso de castigo físico ou de tratamento cruel ou degradante, como formas de correção, disciplina, educação ou qualquer outro pretexto, pelos pais, pelos integrantes da família ampliada, pelos responsáveis, pelos agentes públicos executores de medidas socioeducativas ou por qualquer pessoa encarregada de cuidar deles, tratá-los, educá-los ou protegê-los.

${ }^{9}$ Art. 1.634. Compete a ambos os pais, qualquer que seja a sua situação conjugal, o pleno exercício do poder familiar, que consiste em, quanto aos filhos: I - dirigir-lhes a criação e a educação;
} 
simples leitura de tais dispositivos legais já demonstra que não há neles qualquer previsão expressa que imponha os pais a obrigação de indenizar seus filhos no caso desses não manifestaram satisfatoriamente determinadas atitudes emocionais ou afetivas. 0 texto legal estabelece, sim, deveres diretivo aos pais no sentido de prover os meios materiais necessários tanto para a integral subsistência física da criança (ao garantir direito à vida, saúde, alimentação etc...), quanto para a sua formação intelectual, psíquica, moral e cultura (ao garantir o direito à educação, lazer, convivência familiar e comunitária etc...). A figura paterna, portanto, é, de fato, responsável por oferecer aos seus filhos todos os recursos materiais (que, por óbvio, estejam dentro das suas condições financeiras) que se mostrem indispensáveis ao custeio dos bens que permitirão que o filho cultive todas as suas potencialidades físicas e psicossociais. No entanto, esses deveres diretivos que a legislação citada apresenta ao pai podem ser todos atendidos por meio de custeio financeiro, razão pela qual podem ser convertidas, puramente, em questões patrimoniais. Com efeito, caso não cumpridos tais deveres, poderá, sim, o pai ser coagido a indenizar materialmente o filho que não teve a possibilidade de usufruir de determinados bens que deveriam ter sido arcados pelo seu progenitor, inclusive, sendo o pai obrigado a arcar, materialmente, com despesas de acompanhamento psicológico do filho por determinados traumas psíquicos que eventuais negligências continuadas que o genitor tenha causado. Além disso, a omissão paterna mais grave poderá até provocar outra espécie de sanção jurídica que poderá levar à perda do poder parental. Nada disso, porém, indica a presença na legislação de regência de um dever jurídico de o pai manifestar determinado estado anímico emocional em relação aos seus filhos, o qual, supostamente, permitiria fosse quantificado e qualificado pelo direito as atitudes afetivas que deveriam ser praticadas minimamente pelos pais, de modo a criar, no caso de não atendido satisfatório do critério jurídico que avalia a manifestação afetiva do pai para como seu filho, um direito subjetivo do seu descendente de receber determinada reparação pecuniária. Dito de outro modo, tais regras positivas, mesmo que fixem direitos aos filhos e competências/deveres aos pais, de modo algum estão estabelecendo expressamente que os pais possam ser, juridicamente, forçados a agir com aparência de atenção, carinho e cuidado afetuoso para com a sua prole, sob pena de pagamento de indenização pecuniária 
em razão de suposta negligência afetiva. Aliás, mesmo que assim viesse a dispor tais normas (o que, aliás, vinha sendo pretendido pelo legislador por meio de projetos de lei ${ }^{10}$, entendemos que tais regras hipotéticas seriam não apenas inócuas ou ineficazes, mas representariam padrões normativos inadequados e indesejáveis para a organização jurídica de uma sociedade humana (talvez tal medida jurídica, adota em larga escala, possa gerar efeitos colaterais negativos ou até socialmente nefastos).

$\mathrm{Na}$ verdade, caso analisado com maior profundidade o argumento do "dever de indenizar em razão da ausência de impedimento legal", percebe-se que ele se fundamenta em uma antiga e conhecida pressuposição que é típica do ideário positivista, qual seja a pressuposição de que a integralidade do conteúdo do direito estaria sempre à disposição dos atos voluntários do legislador, o qual seria o responsável primário para a escolha das estruturas normativas que seriam introduzidas no ordenamento jurídico. Aliás, Hans KELSEN ${ }^{11}$ foi o filósofo do direito que ficou mais conhecido por defender que o sistema jurídico-normativo poderia receber absolutamente qualquer conteúdo - mesmo que absur$\mathrm{do}^{12}$-, bastando, para isso, que o legislador, por meio de seu ato de vontade, desejasse produzir uma norma jurídica que regulasse, hipoteticamente, determinada classe de condutas humanas, atribuindo a essa uma consequência jurídica negativa ou positiva. Desse modo, na perspectiva do positivismo jurídico, o sistema normativo do direito não estaria, a princípio, submetido a qualquer limitador lógico nem ontológico, pois estaria autorizado a trazer para dentro do escopo regulatório do direito toda e qualquer ação humana.

No entanto, conforme se pretende argumentar, o pressuposto positivista que leva a uma espécie de absolutismo regulatório por parte do direito, de acordo com o qual inexistiria qualquer aspecto da existência

\footnotetext{
${ }^{10}$ O Projeto de Lei do Senado $\mathrm{n}^{\circ} 700$, de 2007, pretendia modificar a Lei 8.069/90 (ECA) para caracterizar o abandono moral como ilícito civil e penal. No entanto, em 26.12.2014 a matéria foi arquivada.

11 "Eine norm kann auch einen sinnlosen Inhalt haben. Dann ist aber keine Interpretation imstande, ihr einen Sinn abzugewinnen." (KELSEN, 2008, p. 114).

${ }^{12}$ Para se evitar a crítica apressada, cabe aqui ressaltar o óbvio, qual seja: de nenhum modo está-se aqui sustentando que a demonstração de afeto entre pai e filho deva ser compreendida como conteúdo absurdo de uma norma. Apenas pretende-se ressaltar o extremo a que chega o ideário positivista com uma pretensão de criar um absolutismo normativo, em que qualquer conduta humana pode ser regulada pelo direito, desde que assim deseje o legislador e o aplicador do direito.
} 
humana que não pudesse ser absorvido por padrões normativos e coercitivos do direito, já veio a ser rechaçado por inúmeros teóricos do direito (inclusive por aqueles de viés positivista).

\section{2. "A possibilidade de mensuração, controle e regulação estatal dos processos emocionais internos dos indivíduos"}

A Ministra Relatora do RESP 1.159.242 afirma que a questão de fundo envolvida em casos de indenização moral pelo chamado abandono afetivo envolve, em tese, avaliações de "alto grau de subjetividade", tocando em "elementos intangíveis", na medida em que caberá ao aplicador do direito analisar concretamente aspectos de "afetividade, amor, mágoa" que tenham transcorrido no seio de unidades familiares. Isso porque a definição acerca da ocorrência de dano indenizável nesses casos exigiria avaliar especificamente a manifestação de atitudes emocionais positivas que seriam esperadas de uma figura parental durante o período de convivência com seus filhos. Como se vê, portanto, a questão jurídica em pauta pressupõe, antes de mais nada, saber se é plausível e legítimo exigir-se de autoridades públicas responsáveis pela aplicação do direito que venham a medir, controlar e impor determinada escala de intensidade no que se refere aos estados emocionais internos que um pai (ou mãe) deveria projetar em relação ao seu filho durante o período da criação e formação dessa criança.

A pergunta que se impõe responder, desse modo, é se caberia ao direito avaliar os processos emocionais internos que os indivíduos devem expressar dentro de um contexto fático específico, sob pena de sofrerem determinadas consequências jurídicas. Nesse ponto, algumas distinções relevantes se impõem.

Primeiramente, impõe-se ressaltar que a possível dificuldade que se apresenta no caso do denominado abandono afetivo não diz respeito, propriamente, ao alto grau de "subjetividade" das relações afetivas envolvidas nem ao suposto fato de estados emocionais conterem "elementos intangíveis". Ninguém disputaria que, conceitualmente, os estados anímicos dos indivíduos, principalmente toda a gama de emoções que esses podem projetar, apresentam traços subjetivos que, em parte, não são revelados ao escrutínio racional de terceiro. Isso, porém, de nenhum modo significa dizer que toda e qualquer manifestação emocional ou 
afetiva seja necessariamente irracional ou integralmente desprovida de elementos normativos que permitam a sua avaliação em termos de certo ou errado. Nesse ponto, mostra-se extremamente esclarecedor o estudo de NUSSBAUM (1995) sobre a racionalidade de determinadas emoções ${ }^{13}$, bem como sobre a necessidade de o direito regular e, eventualmente, coibir a manifestação de determinados estados emocionais em certos casos. Aliás, a ideia de emoções racionais que são pressupostas pelo direito pode ser exemplificada pelo caso da legítima defesa em que se mostra necessário analisar, juridicamente, o estado anímico de determinado agente, na medida em que o aplicador do direito deverá avaliar se o medo, o temor, o abalo emocional experimentado pelo indivíduo, em razão de risco de violação de sua integridade física ou de terceiro, foi adequado e justificado ao cometer os atos de força contra o seu agressor com o proposito de conter a violência por esse praticada. Nesses casos, a conduta de autodefesa somente se considera resguardada pelo direito, de modo a não gerar punibilidade, nas situações em que o agente tiver manifestado atitude emotiva verossímil e proporcional ao risco de agressão, sob pena de incorrer em excesso de legítima defesa.

Com efeito, impõe-se reconhecer que o direito, em determinados casos, deverá, sim, avaliar emoções dos particulares, razão pela qual possui o direito autoridade para fixar padrões normativos que se prestarão a estabelecer critérios objetificadores de determinadas atitudes emocionais que poderão ser qualificadas como adequadas ou inadequadas em determinados contextos jurídicos. Isso, no entanto, não significa dizer que o direito possui legitimidade para regular toda e qualquer manifestação emocional que seja experimentada pelo indivíduo. Certas emoções e estados sensitivos dos particulares, por óbvio, não podem ficar ao alcance da regulação estatal e do controle jurídico, pois, se as-

\footnotetext{
13 "Appropriate emotions are useful in showing us what we might do, and also morally valuable in their own right, as recognitions of the char-acter of the situation before us. Furthermore, they motivate appropriate action. On the other hand, not all emotions are good guides. To be a good guide, the emotion must, first of all, be informed by a true view of what is going on - of the facts of the case, of their significance for the actors in the situa-tion, and of any dimensions of their true significance or importance that may elude or be distorted in the actors' own consciousness. Second, the emotion must be the emotion of a spectator, not a participant. This means not only that we must perform a reflective assessment of the situation to figure out whether the participants have understood it correctly and reacted reasonably; it means, as well, that we must omit that portion of the emotion that derives from our personal interest in our own well-being." (NUSSBAUM, 1995).
} 
sim fosse, correríamos o risco de ingressarmos no pior dos Estados totalitários.

Assim, o problema a ser enfrentado no caso em discussão não se dá em razão do suposto traço subjetivo ou intangível das atitudes afetivas que se esperam sejam manifestadas por um pai em relação à sua prole. A questão central de disputa está alhures. Na verdade, considerando que não são todas as emoções que podem ser objeto de controle pelo direito, deve-se identificar qual o traço específico daquelas atitudes emocionais e sensitivas referidas pela Ministra Andrighi - tal como "afetividade, amor, mágoa" - que efetivamente podem ficar sob o jugo do poder impositivo do direito.

Considerando-se, precisamente, o traço coercitivo de que se vale o direito para fazer impor os seus padrões normativos, deve-se reconhecer que somente poderão ser reguladas por instrumentos jurídicos aquelas atitudes emocionais em relação as quais seja plausível ou se exigir forçadamente do agente - o indivíduo que assumiria a incumbência de externar adequadamente determinado conjunto de emoções - a sua manifestação ou se esperar que esse indivíduo pudesse ter, por seu livre arbítrio, manifestado atitude sensitiva diversa, nos casos de desobediência aos parâmetros emocionais esperados pelo direito. Isso significa dizer que algumas relações humanas de cunho emocional podem ser estimuladas ou coibidas por meio de coerção, enquanto outras ações que visam a criar vínculos de empatia ou de afeto entre seres humanos, simplesmente, não poderão ser criadas artificialmente por meio de imposições externas. Isso ocorre pelo simples motivo de algumas emoções humanos, bem como os vínculos formados com base nelas, somente poderem ser expressadas mediante plena espontaneidade e autonomia do agente humano, de modo que é verdadeiro contrassenso falar-se em coerção externa que imponha a formação desse tipo de relação humana. Dito de outro modo, tais expressões humanas de afeto, empatia, carinho ou atenção para com terceiros somente podem ser manifestadas quando houver absoluta liberdade em externar tais emoções e sinceridade do indivíduo em desejar formar, voluntariamente, tais vínculos humanos, motivo pelo qual qualquer tentativa de o direito regular e controlar tais atitudes emocionais será, simplesmente, inócua.

Cabe aqui ilustrar três tipos de vínculos humanos que pressupõem a manifestação de atitudes emotivas e empáticas que somente 
adquirem sentido verdadeiro quando praticadas de modo espontâneo, autônomo e sincero, sendo, absolutamente, impraticável e até contraditório pensar em regulação e coerção pelo direito que obrigue alguém a externar ou deixar de externar tais sensações em relação a ou em benefício de outrem. Aqui citamos os casos da amizade, da caridade e da admiração. Todas essas situações pressupõem, por certo, que o agente humano que pretenda manter para com outrem uma dessas relações tenha manifestado uma série de estados emocionais e criado laços de empatia com os outros partícipes desses vínculos, relações essas que somente poderão ser produzidas tanto pelo agente quanto pelo receptor das respectivas atitudes emocionais quando estas tenham sido externadas de modo absolutamente livre, espontâneo e sem imposição externa. Ora, amizade coagida simplesmente não representa verdadeira amizade. Caridade que tenha sido praticada por coerção será apenas um simulacro de ato caridoso. Admiração pelo mérito ou talento de outrem que não parta de um reconhecimento sincero do admirador em favor daquele alvo de admiração não será, de fato, ato de admiração. Exatamente por isso, representa verdadeira contradição em termos falar-se em amizade coagida, ou em caridade imposta ou ainda em admiração forçada.

Por essa razão, o direito é simplesmente incapaz de regular e controlar, por seus instrumentos de coerção, as relações humanas de amizade, caridade e admiração. A eficiência do direito depende da utilidade com que seus instrumentos de coerção podem ser aplicados, de modo que, nas situações específicas acima apontadas, mostra-se, semanticamente, contraditório pensar-se em imposição coativa pelo direito. Assim, nesses casos, portanto, não será o direito apenas carente de toda a legitimidade na sua pretensão de regular tais vínculos afetivos e empáticos entre seres humanos, mas será, em verdade, de todo inútil mesmo que o aplicador do direito, arbitrariamente, pretenda assumir essa ingrata tarefa ${ }^{14}$.

\footnotetext{
${ }^{14}$ Por exemplo, se o legislador viesse a criar lei obrigando todos os vizinhos residenciais a se considerarem amigos, sob pena de pagamento de multa pecuniária, seria tal lei absolutamente inócua na sua pretensão de criar novos vínculos de amizade. Mesmo que sob temor de pagamento de multa vizinhos passassem a conviver com maior frequência, certamente nenhuma relação de amizade verdadeira estaria sendo produzida no mundo. Ou ainda, se o legislador instituísse a "lei da caridade" obrigando cada cidadão a "doar" a uma família carente o valor de um salário mínimo, sob pena de san-
} 
Como se verá, as relações afetivas e amorosas compartilham o mesmo status existencial e moral que as relações de amizade, caridade e admiração, pressupondo sempre uma manifestação livre, espontânea, autônoma e sincera, estando, por isso, imune a qualquer tentativa de coerção jurídica.

\section{3. "A natureza voluntária dos vínculos emocionais"}

Como regra, no Direito, a pretensão de se imputar responsabilidade jurídica a um indivíduo pressupõe que a ação por ele praticada possa ser a ele atrelada em razão de determinado ato de vontade (real ou presumido) que deverá ser assumido como o móvel ou a causa da imputação pretendida. Assim, a livre manifestação de vontade do particular normalmente representa exigência mínima para que se possa responsabilizá-lo por desvios de condutas qualificadas pelo direito como obrigatórias. Aliás, não é por outro motivo que nas situações concretas em que não se poderia exigir, forçadamente, conduta diversa do indivíduo, a responsabilização jurídica mostra-se ilegítima ou inviável. Percebe-se, claramente, que aqueles que defendem a necessidade de indenização nos casos do chamado abandono afetivo partem irrestritamente desse pressuposto, idealmente projetando um cenário jurídico em que o pai negligente possa ser acusado de atitudes omissivas que ele voluntariamente desejou, imaginando-se que a negativa de dedicar atenção afetiva e de direcionar outros sentimentos positivos aos seus filhos tenha se dado por motivações internas por ele absolutamente controláveis, como se ele pudesse ter, livremente, escolhido de modo diverso no passado, com o intuito de evitar as frustrações e mágoas que foram experienciadas pela criança durante a sua criação e formação psicossocial.

$O$ voto da Ministra Relatora no RESP 1.159.242 parte precisamente desse pressuposto básico da responsabilidade civil, ao sustentar que

\footnotetext{
ção, novamente não estaríamos produzindo mais cidadãos com espírito caridoso. Por fim, nenhuma decisão judicial poderia forçar um indivíduo a manifestar admiração pelo status de alguém, tal como se deu no curioso caso em que juiz processou o porteiro de seu condomínio ao argumento de que esse não lhe garantia tratamento condizente com a sua posição de autoridade, ao negar-se a chamálo de "Doutor" (cabe observar que o Tribunal de Justiça do Rio de Janeiro chegou a conceder liminar favorável ao magistrado que se sentiu agredido, tendo porém o STF negado seguimento ao Recurso Extraordinário que acabou sendo interposto pelo Juiz - Processo n. 20050020034244 e Al 860598, Ministro Lewandowski, 28/04/2014).
} 
a formação do vínculo parental seria "fruto, sempre, de ato volitivo" do genitor (negrito no original), motivo pelo qual estaria o Judiciário autorizado a avaliar o nexo causal estabelecido entre a atitude omissiva voluntária da figura parental e o dano extrapatrimonial vivenciado pela criança que sofreu a privação dos contatos afetivos que deveria ter recebido do seu pai. Isso seria viável porque, estando tais manifestações sensitivas dentro do escopo do livre arbítrio humano, poderia o aplicador do direito mensurar e controlar as projeções de atenção e cuidado afetuoso que um pai deveria ter direcionado ao seu filho, de modo penalizar os seus eventuais desvios emocionais por ele cometidos.

Esse pressuposto, porém, exige que se aceite uma hipótese teórica acerca da composição emocional do ser humano que, além de contraintuitiva e inverossímil, mostra-se simplesmente incompatível com a forma pela qual naturalmente compreendermos o agir humano, no que se refere a sua projeção de sentimentos verdadeiros e sinceros em relação a terceiros ${ }^{15}$. Em realidade, nenhuma relação afetiva e emocional, mesmo que possa pressupor uma parcial influência de atos intencionais do indivíduo, jamais poderia ser caracterizada como ato puramente voluntário do sujeito que deveria manifestar essa ou aquela atitude emocional. Em síntese, o ser humano quase nunca está em perfeito e absoluto controle de suas projeções emocionais, razão pela qual, na maior parte dos casos, não pode livremente escolher quem será o destinatário do seu afeto, carinho, atenção, amor, amizade etc... Por isso, um dos grandes paradoxos existenciais do ser humano é que os seus vínculos afetivos partem, simultaneamente, de elementos intencionais (por óbvio, não formamos vínculos afetivos aleatoriamente) e de fatores internos espontâneos que não são perfeitamente controláveis. E isso não deixa de ser verdadeiro mesmo no caso mais intenso das relações intrafamiliares. É precisamente por isso que o direito se mostra integralmente incapaz de mensurar e regular esse tipo de interação humana, sendo estéreis as medidas punitivas impostas àqueles que - por evidentes falhas morais - se mostraram inaptos na formação de vínculos afetivos com os seus filhos.

Essa constatação, por mais dura que possa soar, representa apenas um fato da vida, o qual jamais poderá ser superado nem modificado

\footnotetext{
${ }^{15}$ Sobre a natureza das emoções humanas e a sua importância no Direito, vide NUSSBAUM, 2004.
} 
por mais que assim deseje o legislador bem intencionado ou o juiz preocupado com o bem-estar de crianças emocionalmente traumatizadas. Cabe mais uma vez esclarecer que não se assume aqui nenhuma postura indiferente nem obtusa diante de pais negligentes que se negam a formar vínculos afetivos que são, de fato, fundamentais para a adequada formação moral e psíquica de crianças. É claro que se pode desejar - em um plano moral - que todos os pais no mundo amem os seus filhos, mas isso não permite que se possa querer, juridicamente, por meio de coerção, que cada entidade parental manifeste adequadamente atitudes afetivas em relação aos seus sucessores. Conforme será analisado no item IV, tal medida condenatória não será apenas inócua, em termos de eficácia jurídica ${ }^{16}$, como, inclusive, poderá gerar, caso adotada em sociedade em larga escala e por tempo prolongado, efeitos colaterais nefas$\operatorname{tos}^{17}$.

\section{4. "A fabricação do conceito de cuidado afetivo"}

Como já referido nos itens anteriores, a Ministra Nancy Andrighi, Relatora do Acórdão proferido no RESP 1.159.242, percebe, com certa clareza, algumas das dificuldades que deveriam ser superadas para que pudesse justificar a condenação de um pai que tivesse, gravemente, negado carinho, atenção e afeto ao seu filho. Não tem ela a intenção de abertamente reconhecer que o direito poderia obrigar alguém a amar outrem. Também chega a reconhecer que não seria o direito capaz de reconstruir vínculos afetivos dentro do seio familiar, principalmente por meio de instrumentos jurídicos sancionatórios. No entanto, indiretamente, em alguns momentos do seu Voto, a Ministra deixa a transparecer que, no fundo, a questão jurídica em disputa toca, sim, na avalia-

\footnotetext{
${ }^{16}$ É implausível imaginar que a prática reiterada de condenações judiciais de genitores negligentes venha a reforçar, no futuro, a formação de vínculos afetivos entre pais e filhos. $O$ temor do pai em ser forçado a pagar indenizações pecuniárias a sua prole dificilmente será assumido como motivação adicional para esse querer dedicar atenção, carinho e afeto à sua criança.

${ }^{17}$ Pode-se facilmente imaginar que os pais negligentes que sejam condenados a pagar indenização pecuniária aos seus filhos venham a nutrir em relação a eles, no futuro, tudo menos afeto, intensificando-se, em verdade, os sentimentos de mágoa e ressentimento entre eles. Teremos, assim, com grande probabilidade, um fenômeno que podemos aqui denominar de perpetuação de animosidade $\mathrm{e}$ mágoa dentro do núcleo familiar, em que a condenação judicial apenas inaugura um novo ciclo de agressividade e violência.
} 
ção (e por consequência regulação jurídica) de manifestações emocionais do pai para com seu filho que deveriam ser caracterizadas como indispensáveis para a adequada formação psíquica e moral da criança. Como se vê, a resolução das disputas jurídicas envolvendo o abandono afetivo parental cria uma encruzilhada, na medida em que, de um lado, se reconhece a impraticabilidade de se pretender controlar pelo direito estados emocionais internos que, conceitualmente, somente se manifestam de modo autônomo, espontâneo e sincero, mas, de outro lado, se assume o desejo (bem intencionado) de não se deixar impune pais que foram omissos na formação emocional dos seus filhos, os quais, portanto, devem ser penalizados por essa negligência, mesmo que isso exija a utilização de medidas condenatórias que possam ser desprovidas de qualquer eficácia social ou até ser contraproducente. Com efeito, essa questão jurídica, se bem compreendida, exigiria a superação de uma evidente contradição, qual seja: como se poderia legitimamente responsabilizar e penalizar alguém por não ter adequadamente externalizado determinadas atitudes afetivas, as quais, conceitualmente, somente se concretizam de modo efetivo quando manifestadas pelo agente como plena sinceridade, espontaneidade e autonomia?

Ciente da dificuldade de se superar tal contradição, a Ministra Andrighi, inteligentemente, vale-se de uma criativa estratégia argumentativa que não chega a solver a contradição, mas que, em verdade, abre um caminho alternativo que, intencionalmente, pretende evitar a encruzilhada antes referida. Com efeito, a Ministra, não querendo incorrer nos riscos de ser acusada de pretender coagir, judicialmente, alguém a manifestar amor ou carinho18, vale-se da estratégia argumentativa por meio da qual fornece ao seu auditório um novo conceito, o qual tem pretensão de, supostamente, ser mais específico (em comparação aos termos amor ou carinho) e mais esclarecedor da relação jurídica que estabelece os deveres dos pais para com seus filhos. Tal novel conceito poderia ser denominado de "Cuidado como valor jurídico". Para esclarecer o sentido próprio dessa importante ideia que estará sendo trazida

\footnotetext{
${ }^{18}$ É interessante notar que, originalmente, os debates jurídicos sobre o chamado abandono paterno destacavam, com transparência e clareza, que a omissão que estaria sendo qualificada como ilícita e, portanto, passível de indenização, seria aquela referente aos vínculos de amor, carinho e afeto que os genitores deveriam direcionar à sua prole.
} 
para dentro do nosso ordenamento jurídico, a Ministra cita doutrina que afirma:

"o ser humano precisa cuidar de outro ser humano para realizar a sua humanidade, para crescer no sentido ético do termo, razão pela qual "atitudes de não-cuidado ou ser descuidado em situações de dependência e carência desenvolvem sentimentos, tais como, de se sentir impotente, ter perdas e ser traído por aqueles que acreditava que iriam cuidálos."19

Transcreve a Ministra, ainda, importante lição do famoso Psicoterapeuta Winnicott, no sentido de que um bebê privado de algumas coisas correntes, mas necessárias, como um contato afetivo, está voltado, até certo ponto, a perturbações no seu desenvolvimento emocional"zo. Diante dessas constatações, conclui a Ministra que "o cuidado é fundamental para a formação do menor e do adolescente; ganha o debate contornos mais técnicos, pois não se discute mais a mensuração do intangível - o amor - mas, sim, a verificação do cumprimento, descumprimento, ou parcial cumprimento, de uma obrigação legal: cuidar."21 Desse modo, ressalta a Ministra que "não se fala ou se discute o amar e, sim, a imposição biológica e legal de cuidar, que é dever jurídico, corolário da liberdade das pessoas de gerarem ou adotarem filhos".22

Na visão da Ministra, o amor seria um sentimento subjetivo, intangível, condicionada à motivação individual e impossível de ser precisamente materializado juridicamente. 0 cuidado, por sua vez, teria elementos objetivos, possíveis de verificação e comprovação de seu cumprimento, exigindo ações concretas e voluntárias, tais como a presença, o contato - mesmo que não presencial -, e a exteriorização do afeto de maneira simétrica ao direcionado a outros filhos. Tal visão acaba sendo sintetizada pela seguinte frase, que acabou cunhando-se em verdadeiro slogan: "Em suma, amar é faculdade, cuidar é dever".23

\footnotetext{
${ }^{19}$ Citação feita pela Ministra Nancy Andrighi no voto do Recurso Especial n. 1.159.242-SP, p. 9.

${ }^{20}$ Ibidem, p. 10.

${ }^{21}$ Expressão utilizada pela Ministra Nancy Andrighi no voto do Recurso Especial n. 1.159.242-SP, p. 10.

22 Ibidem, p. 11.

${ }^{23}$ Idem.
} 
Tal afirmação, porém, por mais criativa que seja, contém uma grave impropriedade lógica que acaba invalidando o argumento como um todo. Isso porque o cerne da diferenciação pretendida pela Ministra Andrighi contrapõe dois conceitos (descritivos de formas afetivas de interação humana) como se ambos tivessem o mesmo grau de especificidade e como se tivessem a mesma dimensão moral e jurídica. Dito de outro modo, pressupõe que, entre os termos amar e cuidar, se poderia estabelecer uma comparação de duas categorias emotivas que não se sobreporiam de qualquer forma, como se fossem, em verdade, duas espécies autônomas de sentimentos humanos, os quais, portanto, poderiam ser contrastados e diferenciados em um mesmo plano. No entanto, na verdade, a noção de amar é mais específica e restritiva do que a de cuidar. De outro lado, a noção de cuidar representa conceito expressivamente mais amplo, o qual poderá sofrer adjetivações das mais variadas (e.g., o cuidar financeiro, o cuidar profissional, o cuidar afetivo e até o cuidar amoroso). Isso significa dizer que a frase "amar é faculdade, cuidar é dever" é desprovida de sentido preciso e contém um sofisma insuperável.

Ora, uma pessoa, sem dúvida, pode cuidar de outrem em termos amorosos (assim, podemos falar em cuidado amoroso) mas também pode cuidar de terceiro sem que haja qualquer intenção afetiva ou amorosa entre os envolvidos. Além disso, um vínculo amoroso, corretamente compreendido, pressupõe necessariamente alguns atos mínimos de cuidado e atenção por parte daquele que é amado. Amar com completa indiferença e desatenção não é conceitualmente um ato de amor. Percebe-se, com isso, que, semanticamente falando, cuidar é gênero, dentro do qual uma das suas espécies é a forma mais intensa de dedicar cuidado a alguém, a qual pode ser qualificada como amor. Desse modo, dentro do conceito genérico de cuidado, estão localizadas inúmeras formas específicas de interação humana, abrangendo inclusive a noção de cuidados profissionais ou meramente financeiros que são dedicados por alguém em benefício de outro ${ }^{24}$. Esse tipo de cuidado financeiro, que obviamente não se confunde com o cuidado amoroso e afetuoso, está

\footnotetext{
${ }^{24}$ Não se está aplicando equivocadamente o termo cuidar quando se afirma que uma enfermeira ou um médico cuida (em termos profissionais) do seu paciente ou quando uma pessoa que deve prover pelo sustento de outro indivíduo hipossuficiente deverá ela cuidar (financeiramente) dessa pessoa carente.
} 
dentro da seara de significação do termo "cuidado". Amar é, pois, um tipo de cuidar (mais intenso e muitas vezes incondicional), mas nem todo cuidar é uma manifestação de amor!

Diante dessas constatações semânticas, percebe-se que a afirmação da Ministra Andrighi incorre em uma evidente impropriedade lógica, pois correlaciona, estabelecendo critérios comparativos, duas expressões que possuem densidade moral e jurídica distintas, uma sendo gênero (abarcante de um universo maior de ocorrências) e outra sendo espécie desse mesmo gênero. Contrapõe ela, portanto, as noções de amor e cuidado como se mesma dimensão prática tivessem. A frase "amar é faculdade, cuidar é dever" peca, pois, por falta de clareza e por defeito lógico, pois qualifica como facultativa uma forma específica de relacionamento humano (o vínculo amoroso) e qualifica como juridicamente obrigatória um tipo de relação que abarca uma gama ainda ampla de vínculos humanos (relações de cuidado de um para com outro), a qual, inclusive, contém em si as próprias relações amorosas que estariam sendo diferenciadas (como já se viu, não é erro linguístico falar em cuidado amoroso). Para tornar mais clara a demonstração de tal impropriedade lógica, a frase da Ministra pode ser traduzida nos seguintes termos: "amar não é dever jurídico, já cuidar é dever jurídico". No entanto, tomando-se a expressão cuidar como gênero, não é logicamente possível que uma das suas espécies tenha uma característica contraditória com um traço necessário do gênero ${ }^{25}$. Seria como se disséssemos, "maça é doce, mas fruta não é". Em verdade, podemos vislumbrar uma adaptação de sentido da frase lançada pela Ministra que não incorrerá na impropriedade lógica apontada, mas que, no entanto, não será capaz de apresentar o resultado por ela alcançado na sua decisão. Adquire sentido a comparação traçada pela Ministra caso a sua intenção tenha sido a de afirmar: "amar é faculdade (i.e. não reflete dever jurídico), já o cuidar financeiro da prole pela figura paterna é dever jurídico". Nesse caso, porém, novamente, estaríamos tratando exclusivamente de deveres jurídico-patrimoniais do pai para com os seus filhos, o que colocaria a questão fora do escopo do abandono afetivo, conforme vem sendo sustentado desde o início deste texto.

\footnotetext{
${ }^{25}$ Obviamente, uma espécie pode ter outras diferenças específicas em relação ao gênero, mas não poderá ter uma qualidade que seja contraditória às qualidades necessárias que caracterizam o gênero, sob pena de não ser uma de suas espécies.
} 


\section{O princípio da dignidade da pessoa humana e a precificação do afeto}

Além da crítica direta às principais razões que compuseram a fundamentação adotada pela Ministra Nancy Andrighi, Relatora do Acórdão proferido no RESP 1.159.242, entendemos que contraargumentos adicionais devem ser analisados com o propósito de demonstrar a inadequação jurídica do entendimento jurisprudencial que acabou se consolidando naquele Acórdão da Corte Superior. Assim, cabe ainda analisar a questão jurídica do chamado abandono afetivo a partir da perspectiva da dignidade da pessoa humana.

Para Immanuel KANT, grande teórico do deontologismo moral e defensor de ideais anti-consequencialistas, para que sejam atendidas as condições mínimas de qualquer moralidade, nenhum indivíduo humano deve ser tratado, exclusivamente, como objeto, ou seja, como um meio de satisfação das inclinações e interesses de terceiro, mas, em verdade, sempre como fim em si mesmo das ações humanas. Essa ideia ilustra a amplamente conhecida terceira formulação do imperativo categórico kantiano (PATON, 1971), in verbis:

Age de tal maneira que uses a humanidade, tanto na tua pessoa como na pessoa de qualquer outro, sempre e simultaneamente como fim e nunca simplesmente como meio. (KANT, 1986, p. 69)

Complementando tal ideia, a dignidade humana foi por ele concebida da seguinte forma:

no reino dos fins tudo tem ou um preço ou uma dignidade. Quando uma coisa tem um preço, pode-se pôr em vez dela qualquer outra como equivalente; mas quando uma coisa está acima de todo preço, e, portanto, não permite equivalente, então tem ela dignidade. (KANT, 1986, p. 77)

Assim sendo, para Immanuel KANT a dignidade (Würde) representa valor moral que fundamenta a existência racional do ser humano, sem a qual o indivíduo estará negando ou sendo privado de sua própria humanidade, sendo, portanto, insubstituível, pois não há equivalente 
que permita a sua mensuração. 0 referido autor destaca que o homem não deve ser transformado em instrumento para a obtenção de quaisquer fins que exclusivamente satisfação vantagens, interesses ou sentimentos de terceiros.

0 imperativo categórico é composto pela exigência de que o ser humano jamais seja visto, ou seja usado, como um meio para, apenas, atingir outras finalidades. De tal modo, o ser humano dever ser sempre considerado como um fim em si mesmo. Isto significa dizer que todas as normas decorrentes da vontade legisladora dos homens necessitam ter como finalidade o próprio homem, a espécie humana. Segundo Maria Celina Bodin de MORAES (2010, p. 117), "o imperativo categórico orienta-se, então, pelo valor básico, absoluto universal e incondicional da dignidade humana. É esta dignidade que inspira a regra ética maior: o respeito pelo outro."

Assim sendo,

de acordo com Kant, no mundo social existem duas categorias de valores: o preço (preis) e a dignidade (Würden). Enquanto o preço representa um valor exterior (de mercado) e manifesta interesses particulares, a dignidade representa um valor interior (moral) e é de interesse geral. As coisas têm preço; as pessoas, dignidade. 0 valor moral se encontra infinitamente acima do valor de mercado, porque, ao contrário deste, não admite ser substituído por equivalente. Daí a exigência de jamais transformar o homem em meio para alcançar quaisquer fins. (MORAES, 2010, p. 117)

A Constituição Federal de 1988 foi a primeira na história do Brasil a elencar a dignidade da pessoa humana como um dos fundamentos do Estado Democrático de Direito (artigo $1^{\circ}$, inciso III). Assim, também, a Carta Magna de 1988 foi a primeira a prever um título próprio destinado aos princípios fundamentais. Assim agindo,

o Constituinte deixou transparecer de forma clara e inequívoca a sua intenção de outorgar aos princípios fundamentais a qualidade de normas embasadoras e informativas de toda a ordem constitucional, inclusive (e especialmente) das normas definidoras de direitos e garantias fundamentais, que igualmente integram (juntamente com os princípios fun- 
damentais) aquilo que se pode - e nesse ponto parece haver consenso denominar de núcleo essencial da nossa Constituição formal e material. (SARLET, 2012a, p. 75)

Após mais de duas décadas de ditadura sob o regime militar no Brasil, a Constituição democrática de 1988 explicitou (no art. $1^{\circ}$, III) a dignidade da pessoa humana como um dos "fundamentos da República". Assim sendo, a dignidade humana não é criação de ordem constitucional, em que pese seja por ela respeitada e protegida. Considerando a sua eminência, a Constituição Federal consagrou-o e proclamou-o entre os princípios fundamentais da República Federativa do Brasil, atribuindolhe o valor supremo de alicerce da ordem jurídica democrática. Como consequência, "da mesma forma que Kant estabelecera para a ordem moral, é na dignidade humana que a ordem jurídica (democrática) se apoia e constitui-se."(MORAES, 2010, p. 119)

0 referido princípio constitucional objetiva assegurar o respeito e a proteção da dignidade humana não somente no sentido de garantir um tratamento humano e não degradante, e tampouco conduz a mero oferecimento de garantias à integridade física do ser humano. Assim sendo,

dado o caráter normativo dos princípios constitucionais, princípios que contêm os valores ético-jurídicos fornecidos pela democracia, isto vem a significar a completa transformação do direito civil, de um direito que não mais encontra nos valores individualistas de outrora o seu fundamento axiológico. (MORAES, 2010, p. 119)

A valorização da pessoa humana funda-se na ideologia cristã. Isso porque, tanto no Antigo quando no Novo Testamento, encontramos passagens que referem que o homem foi criado à imagem e semelhança de Deus. Foi justamente a partir dessa ideia que o cristianismo entende que o ser humano é detentor de um "valor próprio e que lhe é intrínseco, não podendo ser transformado em mero objeto ou instrumento." (SARLET, 2012b, p. 98). Foi o cristianismo que, pela primeira vez, arquitetou a ideia de uma dignidade pessoal, atribuída a cada indivíduo (MORAES, 2010, p. 115). 
Na esteira da concepção kantiana, o professor Ingo Wolfgang SARLET, ao citar a obra de Günter DÜRING (DÜRING, 1956, p. 9 apud SARLET, 2007, p. 380), assim destaca:

a dignidade da pessoa humana poderia ser considerada atingida sempre que a pessoa concreta (o indivíduo) fosse rebaixado a objeto, a mero instrumento, tratado como uma coisa, em outras palavras, sempre que a pessoa venha a ser descaracterizada e desconsiderada como sujeito de direitos.

O vocábulo 'dignidade' deriva do latim dignus - aquele que faz jus a estima e a honra, aquele que é importante. É o referido vocábulo que distingue os seres humanos dos demais seres vivos, sendo a dignidade inerente à espécie humana como um todo. (MORAES, 2003, p. 77)

Assim sendo, a dignidade da pessoa humana "é um valor supremo que atrai o conteúdo de todos os direitos fundamentais do homem, desde o direito à vida." (AFONSO DA SILVA, 1990, p. 93). Com efeito, SARLET (2012a, p 73). preconiza ser a dignidade da pessoa humana em sua completude

(...) qualidade intrínseca e distintiva reconhecida em cada ser humano que o faz merecedor do mesmo respeito e consideração por parte do Estado e da comunidade, implicando, neste sentido, um complexo de direitos e deveres fundamentais que assegurem a pessoa tanto contra todo e qualquer ato de cunho degradante e desumano, como venham a lhe garantir as condições existenciais mínimas para uma vida saudável, além de propiciar e promover sua participação ativa e co-responsável nos destinos da própria existência e da vida em comunhão com os demais seres humanos, mediante o devido respeito aos demais seres que integram a rede da vida.

Ingo Wolfgang SARLET (2012b, p. 101), com base no art. $1^{\text {o26 da }}$ Declaração Universal da ONU (1948), destaca, ainda, que a "dignidade independe de circunstâncias concretas, sendo algo inerente a toda e

\footnotetext{
26 "Todos os seres humanos nascem livres e iguais em dignidade e em direitos. Dotados de razão e de consciência, devendo agir uns para com os outros em espírito de fraternidade."
} 
qualquer pessoa humana, de tal sorte que todos - mesmo o maior dos criminosos - são iguais em dignidade."

O substrato material da dignidade pode ser desdobrado, segundo Maria Celina Bodin de MORAES (2010, p. 120), em quatro postulados: (i) o sujeito moral (ético) reconhece a existência dos outros como sujeitos iguais a ele, (ii) merecedores do mesmo respeito à integridade psicofísica de que titular, (iii) é dotado de vontade livre, de autodeterminação; (iv) é parte do grupo social, em relação ao qual tem a garantia de não vir a ser marginalizado.

Os princípios jurídicos da igualdade, da integridade física e moral - psicofísica -, da liberdade e da solidariedade são corolário desta elaboração. Isso porque o princípio da igualdade justamente decorre do reconhecimento da existência de outros seres humanos iguais; se os iguais merecem idêntico respeito à sua integridade psicofísica, será necessário construir o princípio que protege tal integridade; considerando ser a pessoa essencialmente dotada de vontade livre, será preciso juridicamente garantir esta liberdade; por fim, sendo ela parte integrante do grupo social, disso decorrerá o princípio da solidariedade social. (MORAES, 2010, p. 120)

Ressalte-se que a dignidade da pessoa humana também restou expressamente positivada em outros capítulos da Constituição Federal. Desse modo, a dignidade da pessoa humana se faz presente quando estabelece que a ordem econômica tem a finalidade de assegurar a todos uma existência digna (artigo 170, caput), quando, na esfera da ordem social, fundou o planejamento familiar nos princípios da dignidade da pessoa humana e da paternidade responsável (artigo 226, § $7^{\circ}$ ), além de assegurar à criança e ao adolescente o direito à dignidade (artigo 227, caput). 0 artigo 230 assegura que "a família, a sociedade e o estado têm o dever de amparar as pessoas idosas, assegurando sua participação na comunidade, defendendo sua dignidade e bem-estar e garantindo-lhes o direito à vida". (SARLET, 2012a, p. 76)

SARLET (2012a, p. 71) ressalta que

onde não houver respeito pela vida e pela integridade física e moral do ser humano, onde as condições mínimas para uma existência digna não forem asseguradas, onde não houver limitação do poder, enfim, onde a liberdade e a autonomia, a igualdade (em direitos e dignidade) e os di- 
reitos fundamentais não forem reconhecidos e minimamente assegurados, não haverá espaço para a dignidade da pessoa humana e esta (a pessoa), por sua vez, poderá não passar de mero objeto de arbítrio e injustiças.

Desse modo, a proteção da dignidade do ser humano não pode ser afastada. Isso porque a dignidade da pessoa humana é inegociável e demanda proteção máxima. A referida proteção é conferida pelo legislador constitucional, na medida em que prevê direitos fundamentais e da personalidade. (ALMEIDA NETO, 2013, p. 10)

Do reconhecimento da dignidade humana decorrem os direitos de personalidade. Por essa razão a Constituição Federal de 1988 reconheceu expressamente no artigo $5^{\circ}$, $\mathrm{X}$ os direitos à vida, à honra, à integridade física, à integridade psíquica, à privacidade, dentre outros direitos. Paulo Luiz Netto LÔBO (2001, p. 86) entente que os referidos direitos são essenciais, pois, sem eles, "não se concretizaria a dignidade humana. A cada pessoa não é conferido o poder de dispô-los, sob pena de reduzir sua condição humana; todas as demais pessoas devem abster-se de violá-los.".

Para Pietro PERLINGIERI (2002, p. 157) a personalidade não é um direito

mais um valor (o valor fundamental do ordenamento) e está na base de uma série aberta de situações existenciais, nas quais se traduz a sua incessantemente mutável exigência de tutela. Tais situações subjetivas não assumem necessariamente a forma de direito subjetivo e não devem fazer perder de vista a unidade do valor envolvido. Não existe um número fechado de hipóteses tuteladas: tutelado é o valor da pessoa sem limites, salvo aqueles colocados no seu interesse e naqueles de outras pessoas.

0 fundamento constitucional da dignidade da pessoa humana tem sido frequentemente empregado nas discussões que envolvem o chamado abandono afetivo. Entende-se que o pai que não dedica amor para seus filhos, ou que é incapaz de demostrar afeto, fere a dignidade humana do seu filho e, portanto, justificado estaria seu dever de indenizar. Acerca disso, algumas considerações devem ser feitas. 
Conforme já destacado, entendemos que a ausência do amor paterno pode sim trazer prejuízos a formação da criança, pode sim lhe provocar profunda mágoa e essa dor é, como toda a certeza, incomensurável. Entendemos que o pai que não dedica amor para com seu filho pratica ato moralmente reprovável e não se objetiva, por meio desse estudo, promover a defesa do pai, afirmando que seus atos são escusáveis, tampouco corretos. Entendemos que a busca pela construção de um lar, de uma família dever ser calcada em seu maior lastro: que com toda a certeza é o amor, o carinho, a dedicação afetuosa etc...

No entanto, conforme já demonstrado no tópico II deste estudo, entendemos que o Direito não tem a capacidade nem a legitimidade de mensurar, controlar e regular toda a gama de atitudes emotivas e afetuosas que podem ser expressadas pelo ser humano, mesmo no caso do pai para com seu filho. É simplesmente impraticável pretender impor esse dever moral como se um dever jurídico calcado em uma sanção fosse. E, se não há como impor coativamente tal obrigação, não há como se buscar a reparação pela ausência de algo que sequer nos é imperativo juridicamente fazer.

Anteriormente afirmamos que a dignidade humana é inerente a toda e qualquer pessoa, mesmo ao maior dos criminosos (SARLET, 2012b, p. 101). Assim sendo, objetivando proteger a dignidade do filho, acabamos por desconsiderar a dignidade do pai, tratando-o como objeto, como mero instrumento de satisfação dos desejos monetários do indivíduo adulto que busca reparação pelo ressentimento que tem das mágoas profundas sofridas durante a sua formação. E, se assim objetivarmos fazer, estaremos precificando algo para o qual não há preço, não há equivalente. Lembremos que a dignidade humana pode ser bem ilustrada por meio da máxima kantiana que afirma "quando uma coisa tem um preço, pode-se pôr em vez dela qualquer outra como equivalente; mas quando uma coisa está acima de todo preço, e, portanto, não permite equivalente, então tem ela dignidade."(KANT, 1986, p. 77)

Aliás, a pretensão de se utilizar, economicamente, do pai para se "corrigir" (na verdade, apenas suplantar) ressentimentos experienciados pelo seu filho na infância e na adolescência, pode ainda nos remeter a importantes ensinamentos de Axel HONNETH (2007) no que se refere aos chamados processos de reificação. Um deles é o caso em que a execução de uma práxis perseguida unilateralmente, como um só propósito 
associado a ela, nos leva a perder a atenção com relação a todos os outros motivos, quem sabe até mais originais e relevantes. Um exemplo trazido pelo autor vem o ser o do jogador de tênis que, ambicionando ganhar a disputa a qualquer custo, perde a capacidade de sentir que o seu adversário é, na verdade, seu melhor amigo e que foi por causa dele que começou a jogar a partida. (HONNETH, 2007, p. 96)

Assim sendo, entende-se, com base nos ensinamentos de Immanuel KANT, que a dignidade da pessoa humana não pode ser vista e tratada como objeto, pois, conforme já ressaltado, para ela não há equivalente. No caso do precedente do STJ sendo analisando, percebe-se que a decisão judicial acaba reificando a figura paterna, na medida em que vale-se de mera indenização pecuniária como forma de reparação por mágoas profundas sentidas por jovem durante o seu período de criação, sem que se tenha a mínima pretensão de se recompor qualquer tipo de vínculo afetivo ou moral entre pai e filho. 0 pai, portanto, nesse cenário é tratado, exclusivamente, como objeto, como um instrumento de vingança do filho, que deve - literalmente - pagar por seus defeitos e por suas negligências, não sendo assim considerado sujeito detentor de dignidade, ainda que carente de virtude e ainda que descumpridor de seus deveres morais.

\section{A eficácia social da decisão que pretende regular a manifestação de cuidado afetivo}

Outro ponto que chama a atenção na decisão judicial proferida no RESP 1.159.242 aqui comentada diz respeito à eficácia social que poderá ser alcançada por meio dela em relação aos casos futuros de abandono paterno. De nenhum modo se poderia negar que a Ministra Nancy Andrighi sempre esteve imbuída das melhores intenções possíveis ao condenar o pai omisso a pagar quantia em dinheiro à sua filha que foi privada da atenção e do carinho paternal na sua juventude. Certamente pretendia e pretende ela, além de reparar o mal causado no passado à jovem litigante, que o seu entendimento jurídico venha a impactar sobre a postura familiar e afetiva de outros pais omissos que venham a incorrer na mesma atitude no futuro. Afinal de contas, nenhuma decisão de tribunal superior é tomada para que seu fundamento jurídico geral e abstrato - no caso, os argumentos que levaram a conclusão de que é 
indenizável o dano moral por abandono afetivo dos pais - seja aplicável a um único caso concreto.

Diante disso, cabe questionar que repercussões sociais podemos esperar a partir de tal decisão do STJ. Mesmo que, obviamente, esse tipo de esforço de predestinação seja extremamente complicado de ser realizado com alguma objetividade, uma consequência já pode ser prevista desde já, qual seja, os pais omissos não passarão a dedicar mais carinho, atenção, afeto aos seus filhos a partir do momento que tiverem ciência da decisão condenatória proferida pelo Judiciário. Por um, aqueles pais que, antes da decisão, por incapacidade emotiva ou por puro desvio de caráter, não se mostravam capazes de amar ou de cuidar afetivamente dos seus filhos, certamente continuarão a assim agir. Aliás, mesmo que sejam condenados a desembolsar o valor referente a indenização moral, esses pais continuarão sendo insensíveis afetivamente em relação aos seus filhos.

Em segundo lugar, o temor e o receio de receber uma condenação judicial a pagar quantia em dinheiro não é, de nenhum modo, um instrumento minimamente eficaz para instaurar em alguém um sentimento sincero e verdadeiro no sentido de direcionar afeto e carinho a alguém. Isso pelo simples fato de que nenhum tipo de ato de coerção - judicial ou de outra natureza - será capaz de forçar alguém a modificar a sua postura afetiva. Muito pelo contrário, pois a condenação pecuniária ou a ameaça de recebê-la é, por certo, a forma mais célere e eficaz de se fechar todas as portas para uma possível reconciliação afetiva. Aliás, cabe dizer que uma postura inicial de indiferença, i.e., o descaso afetivo do pai omisso, será, certamente, após a condenação judicial, transformado em raiva e rancor, ceifando, assim, de vez, todo e qualquer vínculo que pudesse ser construído entre pai e filho. Assim, nesses casos, teremos a possível instauração de um fenômeno que denominamos aqui de perpetuação de animosidade e mágoa dentro do núcleo familiar, no qual a concretização, por meio de litígios judiciais, do desejo de vingança do filho contra seu negligente pai apenas estará inaugurando novo ciclo de agressividade e violência entre eles.

Como se vê, portanto, a decisão tomada pelo STJ poderá pavimentar um caminho ainda mais nefasto, prestando, inclusive, um verdadeiro desserviço no que diz respeito à promoção daquele fim que afirma estar realizando, uma vez que a recorrência desse tipo de decisão não iria 
contribuir para melhorias nas relações familiares já fragilizadas, mas poderá intensificar as situações de conflito e inviabilizar de vez qualquer espécie de conciliação. Em verdade, o único resultado efetivo que esse tipo de decisão poderá gerar é o de garantir um retorno financeiro ao filho. Está-se, pois, diante de uma medida jurídica que - provavelmente, de forma inconsciente - tão somente promove uma política pública de monetarização de relações familiares conflituosas, o que, em larga escala, representa, certamente, um remédio perverso para um problema social real.

Assim, também, questiona-se se a criança, após a condenação do pai, encontraria na figura do genitor, que antes o preteriu, "ambiente para reconstruir o relacionamento ou, ao contrário, se veria definitivamente afastada daquele pela barreira erguida durante o processo litigioso?"27

Entendeu a 4 a Turma do STJ que:

por certo um litígio entre as partes reduziria drasticamente a esperança do filho de se ver acolhido, ainda que tardiamente, pelo amor paterno. 0 deferimento do pedido, não atenderia, ainda, o objetivo de reparação financeira, porquanto o amparo nesse sentido já é providenciado com a pensão alimentícia, nem mesmo alcançaria efeito punitivo e dissuasório, porquanto já obtidos com outros meios previstos na legislação civil.

Ressalte-se que, no caso do precedente aqui analisado, conforme destacado pelo magistrado ao prolatar a sentença, a genitora da Autora também contribui para com o afastamento do pai. Nesse sentido também se manifestou a $4^{\mathrm{a}}$ Turma do STJ, ao julgar o Resp. 757.411/MG, vejamos:

(...) é preciso levar em conta que, muitas vezes, aquele que fica com a guarda isolada da criança transfere a ela os sentimentos de ódio e vingança nutridos contra o ex-companheiro, sem olvidar ainda a questão de

\footnotetext{
${ }^{27}$ Questionamento formulado pela 4ạ Turma do Superior Tribunal de Justiça, no julgamento do RESP $\mathrm{n}$. 757.411/MG, de relatoria do Ministro Fernando Gonçalves: RESPONSABILIDADE CIVIL. ABANDONO MORAL. REPARAÇÃO. DANOS MORAIS. IMPOSSIBILIDADE. 1. A indenização por dano moral pressupõe a prática de ato ilícito, não rendendo ensejo à aplicabilidade da norma do art. 159 do Código Civil de 1916 o abandono afetivo, incapaz de reparação pecuniária. 2. Recurso especial conhecido e provido
} 
que a indenização pode não atender exatamente o sofrimento do menor, mas também a ambição financeira daquele que foi preterido no relacionamento amoroso.

Com efeito, a decisão do STJ não é apenas inútil e desproporcional no que diz respeito a eficácia social que propõe promover (enquanto absolutamente incapaz de sequer minimizar as consequências negativas das relações familiares que pretende regular), mas é também altamente perversa nos seus possíveis efeitos colaterais, na medida em que, caso seja ampliada sua incidência a todas as demais situações em que negligências afetivas extremas tenham sido cometidas, poderá inviabilizar qualquer tentativa de reconciliação, promoverá ainda mais rancor e raiva de pais omissos para com seus filhos e estará pautando relações familiares em parâmetros integralmente monetários, o que, por certo, não é algo saudável.

\section{Conclusão}

Quando se discute a questão do chamado abandono afetivo, sem dúvida alguma, está-se diante de polêmico caso em que o aplicador do direito - movido por evidente boa intenção - pretende introduzir decisão judicial que instaure e motive política pública que assuma a tarefa de resolver problemas intrafamiliares graves por meio de instrumentos de coerção e de condenações pecuniárias daqueles que se mostraram incapazes de manifestar atitudes emocionais e afetivas em favor de crianças que seriam intitulados a recebê-las durante fase fundamental da sua criação. No entanto, ao assim pretender agir, o Poder Judiciário acabou ultrapassando os limites regulatórios e diretivos do direito, impondo medidas sancionatórias e reparatórias que não são nem capazes de melhorar as condições de convivência dos integrantes de um núcleo familiar nem de concretizar os fins que inicialmente motivaram a implementação da decisão judicial aqui discutida. 0 caso do abandono afetivo, portanto, representa mais uma das situações contemporâneas em que a vida em sociedade se submete a um absolutismo jurisdicional, em que se pressupõe que a integralidade dos conflitos existenciais humanos serão solvidos por meio de disputas judiciais. 
MACINTYRE (2000, p. 91-115) diagnosticou com precisão um dos possíveis excessos da vida contemporânea no que tange ao referido absolutismo jurisdicional que impera na sociedade moderna e subjuga toda a nossa realidade. De acordo com ele, o indivíduo contemporâneo vislumbra o Judiciário como sendo, não apenas a primeira opção para o enfrentamento de todos os seus conflitos, mas também como sendo a via necessária e o local exclusivo para que todos os seus problemas sejam discutidos, enfrentados e resolvidos. Assim, o Judiciário teria o papel de salvaguardar em primeira mão não só todos os tipos de disputas sociais, mas seria a única e exclusiva instituição pública que teria a prerrogativa e a autoridade para dar enfrentamento definitivo de tais conflitos. Todas as outras instâncias de mediação social teriam apenas uma função paliativa e precária no enfrentamento dos problemas rotineiros que os indivíduos enfrentam durante o seu convívio social. Diante disso, nenhuma dimensão da vida humana escaparia do poder deliberatório e decisório do Poder Judiciário. Não seria exagero afirmar, portanto, que o Tribunal representa nos Séculos XX e XXI aquilo que a Igreja foi na Idade Média.

No entanto, é bastante questionável pensar o direito como sendo instrumento social que seja, de fato, capaz de regular e coordenar todas as facetas da existência humana. E é precisamente dentro do exagero de escopo na atribuição de tarefas sociais a serem resolvidas pelo direito que se percebe o traço ilusório de se pretender impor um remédio jurídico contra um real problema social que simplesmente não se afeiçoa aos mecanismos coercitivos que de que dispõe o direito. Ora, um pretenso remédio que não é capaz de minimamente reduzir os efeitos negativos de uma doença - ou de previr a sua ocorrência no futuro - não é, verdadeiramente, um remédio.

Não amar um filho é, sem dúvida, um ilícito moral, mas não é todo vício moral que pode ser reproduzir em um ilícito jurídico, ainda mais um ilícito jurídico que deva ser reparado por meio de reparação pecuniária. No caso concreto do chamado abandono paternal, temos situação ainda mais grave, uma vez que, como se viu, a tentativa de reverter em retorno financeiro o trauma sofrido pela criança que foi privada do carinho paterno, ao invés de contribuir para a minoração desse grave problema social, irá acarretar: 
(i) um aumento na intensidade dos sentimentos negativos entre pais e filhos (rancor, inimizade, relação baseada no temor de uma condenação judicial, relações afetivas falsas ou dissimuladas para evitar litígios);

(ii) a criação de uma tendência de monetarização de relações de afeto, em que pais e filhos passam a pensar o relacionamento afetivo espontâneo em termos de receitas passíveis de serem auferidas ou de risco de despesas que poderão ser arcadas no caso de omissão;

(iii) a incumbência do Estado - i.e. o Poder Judiciário - definir e comensurar as atitudes que são adequadas e suficientes no que diz respeito à manifestação afetiva que os genitores devem manifestar. Ora, talvez na história da humanidade jamais se tenha elaborado um projeto estatal com tamanha ambição totalizante e com semelhante força interventiva na manifestação dos particulares, em que o Estado pretende determinar quando o afeto e o carinho de um indivíduo foi, efetivamente, satisfatório e compatível aos parâmetros fixados por agentes estatais (no caso, membros do Poder Judiciário).

Certamente, alguns poderão contraditar a objeção aqui levantada destacando que o Direito, frequentemente, assume a tarefa de fixar a indenização devida por lesões que foram provocadas a bens intangíveis, incomensuráveis e que não poderiam ser definidos, no que diz respeito ao impacto subjetivo que tal violação provocou na vítima. Por isso, é rotineira a atividade jurídica de fixar indenizações por violações ao direito de imagem, à honra, a atos que causa invalidação, perda de membros ou inclusive a morte de um familiar. Todos esses casos, de fato, bem representam situações jurídicas em que o dano indenizável é incomensurável, na medida em que não é possível uma averiguação precisa, técnica e objetiva do prejuízo individual que tais atos ilícitos provocaram. Qual seria, portanto, a diferença na fixação de indenização nesses casos de bens intangíveis com a possível indenização pelo ato omissivo que provoca também um sofrimento incomensurável nos filhos que são abandonados por um dos seus pais?

A diferença fundamental não está propriamente no tipo de dano que foi provocado - até porque, em todos os casos mencionados, o bem violado é intangível, imaterial e indefinível em termos quantitativos, o que acarreta incomensurabilidade do eventual dano provocado. Na verdade, a diferença está no tipo de ação que é agressiva a tal bem e o tipo 
de intencionalidade que deve ser verificada por parte daquele que age de modo a provocar um mal a outrem.

Nos casos de indenização por dano à imagem, à honra e outras restrições provocadas à personalidade do ofendido (prejuízos estéticos, impedimentos laborativos ou a perda de um familiar) todas pressupõem uma atitude de abstenção (um dever negativo, portanto, um dever de não causar dano - o neminem laedere dos romanos) que não foi cumprida. Pressupõe a intenção de o agente adotar determinado plano de ação, por culpa ou por dolo, enquanto que seria dele exigido o dever de se abster de concretizar tais atos. Pressupõe, ainda, que exista um dever jurídico nos ordenando fazer ou deixar de fazer alguma coisa.

Por outro lado, ao exigir que o pai dedique afeto e carinho ao seu filho, não se está fixando apenas um dever negativo, uma exigência de abstenção em relação a um modo de agir. Está-se, em verdade, impondo deveres positivos ao pai omisso, no sentido de determinar quais atos e gestos deve ele executar para que não venha a incorrer na situação jurídica agora fabricada do abandono afetivo. Tais deveres positivos criam obrigações ativas - não de mera abstenção, portanto - exigindo que o genitor cumpra determinadas ações concretas relacionadas a um suposto ato de afeto, carinho ou cuidado (para se valer da expressão da Ministra Andrighi). No entanto, como já se mencionou, o afeto é conceitualmente uma atitude que é produzida de modo livre, espontâneo e sincero. Atitudes afetivas desprovidas dessa espontaneidade e sinceridade, não são, de fato, atitudes afetivas. Aliás, tais simulacros de afeto são, em muitos casos, a antítese do carinho ou do cuidado afetivo que uma criança em formação necessita, uma vez que uma manifestação insincera de afeto por parte do pai poderá provocar ainda mais danos ao filho.

Assim sendo, cabe aqui questionar se a decisão da $3^{\mathrm{a}}$ Turma do STJ, proferida no RESP 1.159.242 - que entendeu, por maioria, que o abandono afetivo por parte do genitor em relação ao seu filho enseja dano moral - constitui fato da vida passível de ser regulado pelo direito e, por consequência, objeto de reparação pecuniária. Alguns jusfilósofos contemporâneos, tais como Hans Kelsen e Joseph Raz, afirmariam que sim,

que o direito não só estaria apto a apreender e regular todos os fenômenos manifestados na realidade empírica, como também seria peça abso- 
lutamente necessária na transformação dos modelos sociais e no incentivo de atitudes dos particulares. (FERREIRA NETO, 2013)

0 direito, sem dúvida, exerce papel fundamental na sociedade, incentivando condutas socialmente relevantes. Isso não significa dizer, porém, que o Direito possua uma força regulativa ilimitada e absolutamente compreensiva. Entende-se que existem "parcelas da realidade para as quais o Direito, por óbvio, não se presta como instrumento de intervenção. O amor paterno aparenta ser uma destas situações. "(FERREIRA NETO, 2013)

Ressalte-se, entretanto, que ao adotar tal posicionamento não está se negando, de forma alguma, o respeito e proteção à dignidade da pessoa humana e os direitos de personalidade dos indivíduos que compõe essas relações. Afirma-se, apenas, que existem determinados fatos da vida que, infelizmente, não cabem ao Direito regular. Entende-se que, um desses casos, é o intercâmbio afetivo. A figura paterna é, sem sobra de dúvidas, algo extremamente valioso na vida de praticamente todas as pessoas. Assim, a demonstração de afeto de um pai para com seus filhos é algo extremamente positivo, devendo, por certo, ser incentivado e cultivado no meio social e familiar.

0 que se objetivou demonstrar neste estudo é que existem determinadas características morais que não podem ser condenadas, nem reparadas quando violadas, pelo direito. 0 pai que não dedica amor para com seu filho possui, certamente, um defeito de caráter, um problema de virtude. No entanto, o referido defeito de caráter, que o impede de demostrar afeto, não pode ser pelo direito regulado. A demonstração coercitiva de afeto não contribuirá ao bom desenvolvimento dos fi$\operatorname{lhos}^{28}$

Como se viu, a decisão judicial, caso vislumbrada pelo fim que, em tese, se buscava alcançar, mostra-se como um meio ineficiente de se estimular os pais a amarem ou demonstrarem carinho para com seus filhos. Do mesmo modo que os filhos rejeitados também não passarão a

\footnotetext{
${ }^{28}$ Nesse sentido foi o posicionamento adotado pela 4a Turma do STJ, no julgamento RESP $\mathrm{n}$. 757.411/MG, vejamos: "como escapa ao arbítrio do Judiciário obrigar alguém a amar, ou a manter um relacionamento afetivo, nenhuma finalidade positiva seria alcançada com a indenização pleiteada." (REsp 757.411/MG, Rel. Ministro FERNANDO GONÇALVES, QUARTA TURMA, julgado em 29/11/2005, DJ 27/03/2006)
} 
se sentir mais amados após o recebimento da indenização reparadora. Ora, o amor do pai para com seu filho não surgirá baseado no receio de punição nem poderá ser garantido através da conversão em pecúnia deste sentimento. $\mathrm{O}$ amor paterno, na verdade, somente se manifesta de modo espontâneo - nunca coercitivamente -, podendo apenas ser estimulado através da prática moral e da educação. Mas isso é algo que as estruturais formais do Direito não poderão, por si só, promover.

A penetração do Direito no campo que não lhe é próprio também vem a acarretar uma indesejada alteração no plano conceitual, ou seja, relativamente ao sentido que comumente é atribuído à expressão "amor paterno". Suponhamos que a decisão judicial antes relatada torne-se tese de acolhida reiterada nos tribunais. Aqueles pais qualificados como potenciais ofensores às obrigações jurídico-afetivas devidas aos seus filhos requisitarão saber de antemão, com o intuito de se precaverem, quais as condutas típicas que devem ser praticadas por aqueles que desejam afastar a eventual caracterização do ilícito. Caberá, assim, aos tribunais definir quantos passeios, quantos telefonemas ou quantos gestos de carinho serão necessários para se impedir a configuração do descumprimento dos deveres paternos de afeto. 0 Direito necessitará, desse modo, elencar uma série numerada de atitudes e posturas que poderão ser formalmente praticadas pelos pais para que estes passem a ser qualificados, pelo visor jurídico, como figuras afetivas na educação dos filhos, sem que, em nenhum momento, tivessem efetivamente manifestado qualquer ato substancial de afeto. Haverá, pois, a codificação em termos jurídicos de algo artificialmente definido como amor paterno. Desta realidade, surgirá uma curiosa ruptura conceitual, já que, entre pais e filhos, duas relações de amor distintas poderão surgir: primeiramente o que hoje - ainda - compreendemos como amor paterno, estruturado com base em verdadeiras relações de afeto, e, em segundo lugar, o novo amor jurídico, representado por uma série fechada de obrigações que necessitam ser cumpridas com o intuito de se afastar sanções impostas pelo Direito.

A má-compreensão dos limites de atuação do Direito é, sem dúvida, fruto de uma descrença generalizada em relação às instâncias políticas e sociais que, em períodos passados, sempre tiveram força ativa para repreender posturas negligentes, bem como para incentivar as práticas morais. No entanto, a fragilização das instituições sociais bási- 
cas nos dias atuais permite sejam traduzidas em práticas jurídicas toda e qualquer relação intersubjetiva manifestada no ambiente social, em especial a relação de amor que se estabelece entre pais e filhos, que somente deveria ser estimulada pela sociedade mediante o exercício de hábitos morais.

Cabe referir que o Direito não deve ser visto como um instrumento capaz de reprimir todas as práticas reprováveis moralmente. Dito de outro modo, o direito, por obvio, não é o mesmo que a moral. Por isso, atos contrários à moral não são todos geradores de danos reparáveis pelo direito. Nesse sentido, cabe retomar a importante lição de Tomás de AQUINO (2005, p. 585), apresentada no Tratado da Lei, questão n 96, artigo 2, onde o autor, enfrentando a pergunta acerca da possibilidade de a lei humana coibir todos os vícios, responde negativamente dizendo:

(...) a lei é imposta como uma regra ou medida dos atos humanos. A medida deve ser homogênea ao que é medido, (...). Portanto, é necessário que também as leis sejam impostas aos homens segundo a sua condição, (...). 0 poder ou a faculdade de agir procede de um hábito interior ou disposição: com efeito, a mesma coisa não é possível àquele que não tem o hábito da virtude e ao virtuoso, assim como também não é possível à criança e ao homem adulto. E por causa disso não se impõe às crianças a mesma lei que aos adultos: com efeito, muitas coisas são permitidas às crianças que são punidas pela lei nos adultos, ou também são condenadas. E semelhantemente muitas são permitidas aos homens não perfeitos na virtude, as quais não seriam toleradas nos homens virtuosos. Ora, a lei humana é imposta à multidão dos homens e nessa a maior parte é de homens não perfeitos na virtude. $E$ assim pela lei humana não são proibidos todos os vícios, dos quais se abstêm os virtuosos, mas tãosó os mais graves, dos quais é possível à maior parte dos homens se abster; e principalmente aqueles que são em prejuízo dos outros, sem cuja proibição a sociedade humana não pode conservar-se; assim são proibições pela lei humana os homicídios, os furtos e coisas semelhantes. (...)

Deve-se dizer que a lei humana tenciona induzir os homens à virtude, não de súbito, mas gradualmente. E assim não impõe imediatamente à multidão dos imperfeitos aquelas coisas que são já dos virtuosos, como, por exemplo, que se abstenham de todos os males. (...) 
Deve-se dizer que a lei natural é certa participação da lei eterna em nós: e a lei humana é deficiente em relação a lei eterna. Diz, com efeito, Agostinho: "Esta lei que é lavrada para reger as cidades, concede muitas coisas e deixa impunes aquelas que são punidas pela divina providência. Com efeito, não é porque não faz todas as coisas que as que faz devem ser provadas". Portanto, a lei humana também não pode proibir todas as coisas que a lei da natureza proíbe. (grifou-se)

Cabe, por fim, relembrar a frase utilizada como epígrafe do presente artigo:

O principal objetivo da disciplina da responsabilidade civil consiste em definir, entre os inúmeros eventos danosos que se verificam quotidianamente, quais deles devam ser transferidos do lesado ao autor do dano, em conformidade com as ideias de justiça e equidade dominantes na sociedade. (Konrad Zweigert e Hein Kötz)

Entende-se, da leitura de frase acima, que não cabe ao direito, por meio da disciplina da responsabilidade civil, regular todos os eventos danosos que cotidianamente se concretizam. É necessário, primeiramente, avaliar as consequências de cada grupo de acontecimentos para, posteriormente, com base nos ideais de justiça e equidade, estabelecer se o Direito deve regular tais fatos, transferindo, portanto, os danos sofridos pelo lesado ao autor do dano.

Assim sendo, entende-se, com base nos ensinamentos de Immanuel KANT, que a dignidade da pessoa humana não pode ser vista e tratada como mero objeto, pois, conforme já ressaltado, para ela não há equivalente. No caso do precedente analisando, percebeu-se que houve uma reificação (HONNETH, 2007) da figura paterna, na medida em que, em verdade, o que se buscou por meio do litígio judicial foi simplesmente a indenização pecuniária. Desse modo, o pai negligente veio a ser tratado, não na sua dignidade (não obstante venha ele a manifestar certa insuficiência moral ou, talvez, até defeito caráter), mas como objeto, instrumento de satisfação pecuniária referente a ressentimentos e desejos de vingança do filho que foi alvo de grave negligência. 


\section{Referências Bibliográficas}

AFONSO DA SILVA. José. Curso de direito constitucional positivo. 6. ed. São Paulo: Revista dos Tribunais, 1990.

ALMEIDA NETO, Amaro Alves de. Dano Existencial - A tutela da dignidade da pessoa humana Disponível em: <http://www.mp.sp.gov.br/portal/page/portal/cao_consumidor/doutr inas/DANO\%20EXISTENCIAL.doc >. Acesso em: 05/04/2013.

AQUINO, Tomás de. Suma teológica IV. São Paulo: Edições Loyola, 2005.

FERREIRA NETO, Arthur. 0 amor jurídico. Disponível em: $<\mathrm{http}: / /$ www.pailegal.net/forum/viewtopic.php?t=3355> Acesso em: $10 / 05 / 2013$

HONNETH, Axel. Reificación: un studio en la teoria del reconocimiento. Traducido por Graciela Calderón. Buenos Aires: Katz, 2007.

KANT, Immanuel. Fundamentação da metafísica dos costumes. Lisboa: 70, 1986.

KELSEN, Hans. Reine Rechtslehre. Alemanha: Mohr Siebeck, 2008.

LÔBO, Paulo Luiz Netto. Danos morais e direitos da personalidade. Rio de Janeiro. Revista Trimestral de Direito Civil, v.6, p. 79-97, abr./jun. 2001.

MACINTYRE, Alasdair. Theories of Natural Law in the Culture of Advanced Modernity. In.: Edward B. McLean (Org.). Common Truths: New perspectives on natural law. Wilmington: ISI Books, p. 91-115, 2000.

MORAES, Maria Celina Bodin de. Danos à Pessoa Humana. Uma Leitura Civil-Constitucional dos Danos Morais. Rio de Janeiro: RENOVAR, 2003.

. O conceito de dignidade humana: substrato axiológico e conteúdo normativo. In.: Sarlet, Ingo Wolfgang (Org.). Constituição, Direitos Fundamentais e Direito Privado. Porto Alegre: Livraria do Advogado, 2010. NUSSBAUM, Martha. Hiding From Humanity - Disgust, Shame, and the Law. Estados Unidos da América: Princeton University Press, 2004;

Poetic Justice. Estados Unidos da América: Beacon Press, 1995.

PATON, H.J. The Categorical Imperative: A Study in Kant's Moral Philosophy. Philadelphia: University of Pennsylvania Press, 1971. 
PERLINGIERI, Pietro. Perfis de direito civil: introdução ao direito civil constitucional. Traduzido por Maria Cristina de Cicco. 2. ed. Rio de Janeiro: Renovar, 2002.

SARLET, Ingo Wolfgang. Dignidade da pessoa humana e direitos fundamentais. Porto Alegre: Livraria do Advogado, 2012.

A Eficácia dos Direitos Fundamentais: um teoria geral dos direitos fundamentais na perspectiva constitucional. 11. ed. rev. atual. Porto Alegre: Livraria do Advogado, 2012.

As dimensões da dignidade da pessoa humana. Revista Brasileira de Direito Constitucional - RBDC, n. 09, jan./jun., 2007. p. 361-88.

Recebido: 11/03/2015

Received: 03/11/2015

Aprovado: 12/03/2015

Approved: 03/12/2015 